\title{
ARE RACIAL VILIFICATION LAWS SUPPORTED BY FREE SPEECH ARGUMENTS?
}

\author{
BILL SWANNIE*
}

\section{INTRODUCTION}

This article examines the relationship between laws regulating racial vilification and arguments for freedom of speech. ${ }^{1}$ Commonly, it is argued that racial vilification laws are inconsistent with free speech. This article argues that such laws are consistent with and, indeed, supported by arguments commonly made in favour of free speech. Although this article presents arguments in support of racial vilification laws, it does not dismiss the importance of free speech. Rather, it closely examines arguments commonly made in support of free speech, and it identifies the values and assumptions underlying those arguments. In other words, this article examines the philosophical underpinnings of free speech arguments. ${ }^{2}$ Rather than seeing unrestricted speech as a self-evident and unqualified good, it argues that free speech arguments themselves provide justification for regulation of certain types of speech. Clearly identifying the values and assumptions underlying free speech arguments has the potential to improve the quality of debate surrounding the important topic of the regulation of racial vilification. In turn, this may influence the development of legal policy and legal doctrine surrounding legal regulation of this and other forms of speech.

Because this article adopts a philosophical approach, it does not examine whether racial vilification laws are consistent with common law or constitutional principles, ${ }^{3}$ or whether such laws are justified on the basis of empirical evidence. ${ }^{4}$ For the same reason, this article does not focus exclusively on the particular

* Lecturer in Law, School of Law, Victoria University, Melbourne.

1 The concept of 'free speech' is examined in Part III of this article. In this article, 'free speech' refers to freedom of speech and freedom of expression. This article is based on an earlier article: Bill Swannie, 'Freedom of Speech: Do We Know What We Are Talking about?' (2017) 10 Journal of the Australasian Law Teachers Association 110. The author wishes to thank Associate Professor Patrick Emerton and Dr Colin Campbell, and the reviewers and editors, for their assistance with this article.

2 A philosophical approach to the analysis of free speech issues is commonly adopted in the relevant literature: see generally Frederick Schauer, Free Speech: A Philosophical Enquiry (Cambridge University Press, 1982); Jeremy Waldron, The Harm in Hate Speech (Harvard University Press, 2012).

3 The consistency of racial vilification laws with the implied freedom of political communication in the Australian Constitution is discussed in Katharine Gelber and Adrienne Stone (eds), Hate Speech and Freedom of Speech in Australia (Federation Press, 2007); Dan Meagher, 'What Is "Political Communication"? The Rationale and Scope of the Implied Freedom of Political Communication' (2004) 28 Melbourne University Law Review 438; Michael Chesterman, Freedom of Speech in Australian Law: A Delicate Plant (Dartmouth, 2000); Adrienne Stone, 'Freedom of Political Communication, the Constitution and the Common Law' (1998) 26 Federal Law Review 219.

4 See generally Katharine Gelber and Luke McNamara, 'Anti-Vilification Laws and Public Racism in Australia: Mapping the Gaps between the Harms Occasioned and the Remedies Provided' (2016) 39 University of New South Wales Law Journal 488. This article will focus on in principle justifications for racial vilification laws, although these are often difficult to separate from pragmatic or empirical arguments. 
terms or scope of the Racial Discrimination Act 1975 (Cth) pt IIA (' $R D A$ '), ${ }^{5}$ or the equivalent laws of any other country. ${ }^{6}$ Rather than examining the specific terms and scope of any particular racial vilification law, this article examines the interaction between the purposes of racial vilification laws, the harms which such laws seek to prevent, and arguments made in support of free speech. First, it outlines the nature and purposes of racial vilification laws. In general terms, these laws seek to protect members of racial groups from certain harms, and to limit the social harms caused by messages promoting racial prejudice and intolerance. This Part establishes a context for the analysis of free speech arguments which follows. Second, this article outlines the concept of free speech, and particularly highlights its contested and ambiguous nature. Third, this article outlines three types of arguments commonly made in favour of free speech. These may be described as political arguments, arguments based on autonomy and dignity, and arguments based on the value of inquiry. Arguments made by different authors are examined, and the underlying assumptions and values on which these arguments are based will be analysed. ${ }^{7}$ In relation to each type of free speech argument, this article determines whether it might, in fact, support racial vilification laws. ${ }^{8}$

This article concludes that, although racial vilification laws do impose certain limits on particular types of expression, such laws are justified according to the values of free speech. In relation to political (or democratic) arguments for free speech, racial vilification laws are justified because vilifying conduct can exclude its victims from involvement in public debate and decision-making on important social issues. In relation to arguments based on dignity and autonomy, racial vilification can negatively affect individuals and groups targeted by such speech, causing them serious and long-lasting harm. In relation to arguments based on the value of inquiry, racial vilification does not assist the search for truth, and in fact distorts the marketplace of ideas.

\section{THE NATURE AND PURPOSES OF RACIAL VILIFICATION LAWS}

Virtually all democratic countries have laws regulating racial vilification, although the specific terms of the legislation vary considerably between

5 The $R D A$ pt IIA has some unique features, such as including within its scope conduct which is reasonably likely to 'insult' or 'offend' a person, because of the person's race: at s 18C. See below Part IV(B)(5), which examines the concept of 'serious offence' in relation to racial vilification. Apart from this, the particular features of these provisions are not discussed in this article.

6 Many countries, such as the United Kingdom, Canada and New Zealand, have such laws. The United States, where free speech is highly valued, is almost the only advanced democratic country to not have such laws: see Waldron, The Harm in Hate Speech, above n 2, 29.

7 For an earlier example of this approach, see generally Schauer, above $\mathrm{n} 2$.

8 As discussed in Part III of this article, free speech arguments apply to many other topics, such as pornography and defamation, apart from racial vilification laws. This article only considers free speech arguments insofar as they relate to such laws. 
countries. ${ }^{9}$ This seems to reflect the widespread acceptance of the need for such laws in democratic countries, and the equally important need for such laws to reflect local concerns and conditions. ${ }^{10}$ As stated above, this article does not seek to justify any of these laws in their particular details. Instead, it examines the purposes of racial vilification laws, the harms which such laws seek to prevent, and the interaction between these considerations and arguments commonly made in support of free speech. The analysis presented in this article is therefore applicable to justify the racial vilification laws not only of Australia, but of other democratic countries, too. ${ }^{11}$

In essence, racial vilification laws ${ }^{12}$ regulate $^{13}$ conduct which encourages or promotes certain extreme and negative attitudes or emotions towards a person or group of people, based on the person or group's race, colour or ethnic origin. ${ }^{14}$ The promotion of 'hatred' towards a certain racial group is one standard used in such laws. ${ }^{15}$ However, the type or intensity of the attitudes or emotions that must be promoted varies considerably between such laws. ${ }^{16}$ Some laws are limited in that the promotion of particular attitudes or emotions must be achieved by the use of certain means (such as physical harm or property damage),${ }^{17}$ whereas other laws are not limited by such a requirement. ${ }^{18}$ Essentially, racial vilification laws seek to prohibit or restrict the promotion of particular attitudes or feelings towards certain people or groups, based on race.

Typically, racial vilification laws apply only to conduct done 'in public', and they have no application to purely private conversations or conduct. ${ }^{19}$ The purposes of racial vilification laws are directly linked to the harms which such laws seek to prevent. As will be outlined later in this article, racial vilification can cause serious and long-term psychological harm to the individuals and groups which it targets. ${ }^{20}$ It also promotes racist attitudes and beliefs, which can lead to an increase in acts

9 See Sandra Coliver (ed), Striking a Balance: Hate Speech, Freedom of Expression and NonDiscrimination (Article 19, 1992) 75-312.

10 See Luke McNamara, Regulating Racism: Racial Vilification Laws in Australia (Sydney Institute of Criminology, 2002) $14-15,22$, as to the need for racial vilification laws to reflect local concerns and conditions.

11 This article does not examine whether such laws are justified in non-democratic countries.

12 Racial vilification laws are a form of what is known in the United States as 'hate speech' laws: see Waldron, The Harm in Hate Speech, above n 2, 34. Waldron prefers the title 'group-defamation laws': at 34-64.

13 This is either by way of criminal sanctions, or by civil remedies, or by a combination of both.

14 The focus of this article is on racial vilification. However, many jurisdictions also regulate vilification on other grounds, such as gender, sexual preference or religion. Vilification on these other grounds is outside the scope of this article. See generally Coliver, above $\mathrm{n} 9$.

15 Waldron notes that the term 'hate speech' can be misleading, as such laws generally do not require proof of hatred on the part of the speaker; generally, such laws focus on the effect on other people of the relevant conduct: Waldron, The Harm in Hate Speech, above n 2, 34-5.

16 See Coliver, above n 9, 75-312.

17 See, eg, Anti-Discrimination Act 1977 (NSW) s 20D.

18 See, eg, Racial and Religious Tolerance Act 2001 (Vic) s 24(2).

19 The distinction between 'public' and 'private' conduct can sometimes be difficult to draw.

20 Richard Delgado and Jean Stefancic, 'Four Observations about Hate Speech' (2009) 44 Wake Forest Law Review 353, 362. 
of discrimination, prejudice and violence against people of certain races. ${ }^{21}$ Racial vilification harms society in that it undermines the tolerance and acceptance of racial and ethnic diversity which underlies a democratic, multicultural society. ${ }^{22}$ Such laws also protect the dignity or equal standing of all members of society, and, in particular, that of members of vulnerable racial and ethnic minorities. ${ }^{23}$

\section{THE NATURE OF FREE SPEECH: CONTESTED AND AMBIGUOUS}

'Free speech' is both a political concept or principle, and an individual legal right. As an individual right, free speech is recognised under international treaties ${ }^{24}$ and in the constitutions of many countries. ${ }^{25}$ For the reasons outlined in the introduction, this article will focus on free speech as a political concept or principle. At a conceptual level, free speech is 'fiercely debated' ${ }^{26}$ and highly contested. ${ }^{27}$ One major area of dispute and uncertainty pertains to the precise scope of the principle, including the existence and scope of any exceptions. ${ }^{28}$ More fundamentally, however, there is uncertainty regarding the underlying purpose (or purposes) of free speech, and the relationship between free speech and other social values. Racial vilification laws are commonly regarded as an 'exception' to free speech. ${ }^{29}$ One argument commonly made against such laws is that they lack clarity and precision..$^{30}$ In this regard, it is important to note that the concept of free speech is itself extremely uncertain and ambiguous.

One major uncertainty concerns what exactly is meant by speech being 'free'. Specifically, there is disagreement as to whether free speech merely places a restriction on government action, or whether it can also be a justification for certain positive action by the government. ${ }^{31}$ Traditionally, free speech was regarded as merely a restriction on government, and, in particular, on the lawmaking powers of government. ${ }^{32}$ This reflects the assumption of classical liberalism that individual freedoms are most effectively protected by placing restrictions on the

McNamara, above n 10, 22-3.

Ibid 18-20.

23 See Waldron, The Harm in Hate Speech, above n 2, 105-43. This argument is examined further in Part IV(B)(6) of this article.

24 See, eg, International Covenant on Civil and Political Rights, opened for signature 16 December 1966, 999 UNTS 171 (entered into force 23 March 1976) art 19 ('ICCPR').

25 Most famously, freedom of speech is protected by the United States Constitution amend I.

26 Owen M Fiss, The Irony of Free Speech (Harvard University Press, 1996) 1.

27 McNamara, above n 10, 274-5.

28 Ibid 4-5. Some scholars argue that free speech has no exceptions - that it is 'absolute'. This argument is examined in Parts IV(A)(1) and IV(B)(4) of this article.

29 See Eric Barendt, Freedom of Speech (Oxford University Press, $2^{\text {nd }}$ ed, 2005) 172-3.

30 See, eg, Timothy Garton Ash, Free Speech: Ten Principles for a Connected World (Yale University Press, 2016) 219. This article does not comment on these arguments, which are pragmatic rather than principled arguments.

31 See Barendt, above n 29, 100-8.

32 Delgado and Stefancic, 'Four Observations about Hate Speech', above n 20, 355. 
state. ${ }^{33}$ Pursuant to this approach, free speech restricts government's ability to regulate 'speech', or communication between individuals. ${ }^{34}$ Various reasons are given for the need for this restriction on the state, and these reasons are examined in detail below. This purely 'negative' conception of free speech has, however, been challenged in recent times. Scholars such as Owen Fiss contend that arguments commonly made in favour of free speech actually justify a positive role for the state in regulating speech. ${ }^{35}$ Fiss argues that, in modern societies, the harms caused by private speakers may be more serious than the dangers of a powerful state. Therefore, the regulation of certain types of speech, such as racial vilification, may be justified. ${ }^{36}$ The question as to whether free speech is merely a restriction on the state, or whether it can also be a positive ground for regulating certain speech, is central to the issues under consideration in this article, and will be discussed further below. ${ }^{37}$

Free speech is a very broad - and expanding - field of law, philosophy and political science. ${ }^{38}$ Many arguments now classified under the banner of 'free speech' have developed over the course of centuries, and modern debates involving the concept bear little resemblance to the issues to which it originally pertained. ${ }^{39}$ Historically, free speech was closely associated with freedom of the press, and was used to oppose government licensing of newspapers in the $17^{\text {th }}$ century. ${ }^{40}$ For many centuries, and according to authoritative interpretations by William Blackstone, the principle of free speech was regarded as applying only to "prior restraints $^{31}$ - that is, government restraints which prevented a particular work from being published or distributed at all. ${ }^{42}$ Traditionally, the principle had no application to penalties applying after a work had been published or distributed. ${ }^{43}$

In recent decades, the scope of free speech has expanded greatly. As noted above, this article examines arguments in support of free speech, insofar as they apply to the regulation of racial vilification. Arguments for free speech have,

33 Chesterman, above n 3, 39-44. Barendt notes that this conception of free speech is more accurately described as an 'immunity', or a 'disability' (on the state), rather than a 'freedom' in the true sense: Barendt, above n 29, 101-2.

34 Free speech does not apply to all types of conduct commonly called 'speech': see Barendt, above n 29, 74-116.

35 Fiss, above n 26, 9-10.

36 Ibid

37 The distinction made here is slightly different to Isaiah Berlin's distinction between 'positive' and 'negative' conceptions of liberty: see Isaiah Berlin, Four Essays on Liberty (Oxford University Press, 1969) 118-172.

38 See generally Barendt, above n 29.

39 Waldron notes the lack of historical perspective in modern debates over free speech: Waldron, The Harm in Hate Speech, above n 2, 230-1. He notes that modern debates regarding hate speech lack an 'historical dimension'.

40 Chesterman, above n 3, 6-7. Chesterman notes that, historically, free speech is also closely linked with parliamentary privilege.

41 Prior restraints are now commonly known as 'censorship', which is one aspect of the contemporary concept of free speech: see Barendt, above n 29, 122-4.

42 Ibid 6, quoting Sir William Blackstone, Commentaries on the Laws of England (Thomas Tegg, 1830) vol 4, 151.

43 Waldron, The Harm in Hate Speech, above n 2; see also Chesterman, above n 3, 6-7. 
however, been made in relation to a wide range of other subject matters, such as pornography, defamation, sedition, and censorship of books, films and computer games. ${ }^{44}$ Indeed, the topic of free speech may now be regarded as encompassing many areas of law and regulation (such as censorship of books, films and computer games) which were previously considered as separate and distinct areas of law and regulation..$^{45}$ In this sense, 'free speech' is a relatively new title for a set of arguments which have been raised in many different contexts over the course of many centuries.

As a phrase, 'free speech' is a powerful slogan or rhetorical device. ${ }^{46}$ Like 'democracy' and 'liberty' - two concepts with which free speech is closely associated - 'free speech', as a phrase, has a persuasive influence and popular appeal which often seems to exceed the force of its underlying arguments. For example, it is common for free speech proponents (and opponents of racial vilification laws) to refer to the defence of freedom of speech. ${ }^{47}$ These words immediately convey a sense that free speech is valuable, vulnerable and under attack. The words 'free speech' are often used very loosely by politicians, academics and other commentators. ${ }^{48}$ This seems to be at odds with one of the main arguments for free speech, that is, the importance of rational persuasion and logical debate in the discussion of public issues. ${ }^{49}$

Despite this uncertainty and confusion, free speech is an important principle with major implications for the regulation of serious problems in modern society, such as racial vilification. Therefore, the principle itself needs to be rationally justified..$^{50}$ This article will now closely examine the main arguments made in support of free speech.

\section{THREE TYPES OF ARGUMENTS FOR FREE SPEECH}

This Part examines three types of arguments commonly made in support of free speech. In summary, these are described as political arguments, arguments based on dignity and autonomy, and arguments based on the value of inquiry. ${ }^{51}$ These types of arguments are examined separately, for clarity of analysis, however, it is not contended that these types of arguments are logically distinct or freestanding.

See, eg, Chris Berg, In Defence of Freedom of Speech: From Ancient Greece to Andrew Bolt (Institute regulation: see, eg, Peter Molnar, 'Interview with Robert Post' in Michael Herz and Peter Molnar (eds), The Content and Context of Hate Speech: Rethinking Regulation and Responses (Cambridge University Press, 2012) 11, 12-13.

48 McNamara, above n 10, 106-7.

49 See, eg, Thomas Nagel, 'Personal Rights and Public Space' (1995) 24 Philosophy and Public Affairs $83,43-4$

50 See generally Schauer, above $\mathrm{n} 2$.

51 The value of inquiry is also referred to as the 'search for truth': see Barendt, above n 29, 7-13. 
To the contrary, there are many similarities between different types of arguments for free speech. ${ }^{52}$

Analysis of arguments for free speech reveals a complex interaction between the interests of individuals and the interests of groups and society generally. Somewhat paradoxically, many arguments for free speech do not focus exclusively, or even primarily, on the interests of an individual in speaking. ${ }^{53}$ According to many proponents, free speech also encompasses the interests of people in hearing or receiving the communications of others. ${ }^{54}$ This is reflected in the terms in which free speech (or, in modern parlance, 'freedom of expression') ${ }^{55}$ is expressed in authoritative statements. The ICCPR, for example, refers to the right 'to seek [and to] receive ... information'. ${ }^{56}$ There is, therefore, a complex relationship between the ability of an individual to speak, a listener to hear the message, and the social benefit (and, in certain circumstances, the harm) flowing from this process. The apparent expansion, and fluidity, of free speech is illustrated by its development from being considered as merely an individual right to speak, to now being regarded as a collective right to know. ${ }^{57}$

\section{A Political Arguments for Free Speech}

This Part examines political arguments in support of free speech. Often, it is simply asserted that 'freedom of speech is the lifeblood of democracy' ${ }^{58}$ However, statements like this, taken by themselves, are merely rhetorical flourishes. Scholars have however presented specific and detailed arguments connecting free speech with certain aspects of democracy. Conversely, arguments that racial vilification laws are 'undemocratic' in certain ways have also been made. This Part will analyse these arguments, and then draw some conclusions regarding the democratic legitimacy of racial vilification laws. This analysis commences by examining the arguments made by Alexander Meiklejohn, an early proponent of the connection between free speech (which he understood as the absence of government regulation of communication between individuals), and effective 'self-government'. This Part will then consider criticisms of the conclusions reached by Meiklejohn, and, in particular, arguments that the values he espoused actually justify government regulation of speech in certain circumstances. This Part will then address recent arguments that hate speech laws in particular undermine the democratic process, as well as responses to these arguments.

Chesterman notes that different arguments for free speech are based on essentially the same set of values: Chesterman, above n 3, 22.

53 See below Part IV.

54 Ibid.

55 See, eg, ICCPR art 19(2).

56 Ibid (emphasis added)

57 See Fiss, above n 26, 42-4.

$58 R$ v Secretary of State for the Home Department; Ex Parte Simms [2002] 2 AC 115, 126 (Lord Steyn). 


\section{Meiklejohn's Account of Free Speech: Government as the Main Threat to Wise Political Decision-Making by Citizens}

Contemporary discussion of the relationship between democracy and free speech is heavily influenced by the works of Alexander Meiklejohn, who wrote about the connection between 'self-government' and the First Amendment to the United States Constitution in the mid-20 ${ }^{\text {th }}$ century. ${ }^{59}$ Meiklejohn particularly emphasised the importance of voting to the American system of government, and the significance of free speech to voting. ${ }^{60}$

Meiklejohn argued that the American people are 'self-governing', because they are able to choose and authorise their representatives through voting at regular elections. ${ }^{61}$ For Meiklejohn, citizens (rather than their elected representatives) actually hold ultimate political power in the polity. ${ }^{62}$ In this system, elected representatives hold office only temporarily, and are subject to removal through the electoral process. For Meiklejohn, 'self-government' means that there is no distinction between those who make the laws and those who are subject to the laws. ${ }^{63}$ Meiklejohn enthusiastically affirmed the principle of political equality and the virtues of elected governments, as opposed to hereditary monarchs, appointed rulers or other forms of non-democratic government. ${ }^{64}$ These affirmations are particularly powerful in the context of American history, which includes a war of independence from foreign rule, and a civil rights movement which sought to establish equal rights for all citizens.

Meiklejohn argued that the 'entire structure' of self-government rests on free speech, or preventing the government from inhibiting discussion of issues of 'general welfare'. ${ }^{65} \mathrm{He}$ particularly emphasised the importance of citizens being able to criticise government policy, and to dissent from popular opinion. ${ }^{66}$ Meiklejohn asserted that governments should not determine what information or opinions are heard by voters, or try to protect voters from 'dangerous' ideas. ${ }^{67}$ Specifically, governments should not be able to exclude any view on the grounds that it is dangerous, unwise or false. ${ }^{68}$ In his view, exclusion on these grounds would 'mutilat[e] ... the thinking process of the community', and would be

60 Ibid 86

61 Ibid 11-13.

62 Ibid 37

63 Ibid 12. Meiklejohn also asserted that under self-government the '[r]ulers and [those] ruled are the same individuals': at 6.

64 Broad distinctions are sometimes made between 'open', liberal democratic societies, which allow voting and free speech, on the one hand, and 'closed', non-democratic societies and even authoritarian systems of government, which do not allow either, on the other: see, eg, Philip Alston and Ryan Goodman, International Human Rights: Text and Materials (Oxford University Press, 2013) 651-2. This dichotomy is simplistic, as it fails to recognise the many accepted limitations to free speech in democratic systems of government.

65 Meiklejohn, Free Speech and Its Relation to Self-Government, above n 59, 48, 57.

66 Ibid 50,67.

67 Ibid xiii.

68 Ibid 26. 
inconsistent with the government's obligation to serve the people. ${ }^{69}$ Meiklejohn particularly emphasised the need for citizens to make informed and 'wise decisions' at election time..$^{70}$

Several features of Meiklejohn's account of free speech are noteworthy. First, he conceives of free speech purely in negative terms - as a limitation on the power of the state to regulate speech and communication. In this way, he assumes that government regulation of communication is the most serious obstacle to the desired goal of informed and wise electoral decisions. Meiklejohn's underlying distrust of the state, and his concern regarding the misuse of public power, were perhaps justified at the time he was writing. At this time, there was a high degree of concern in the United States regarding sedition laws, which specifically punished speech which threatened the existing system of government. These laws were vague, and were used by the government to stifle criticism and to suppress discussion of alternative political views including, most notably, communism. ${ }^{71}$ However, as will be outlined in the following Part, threats to informed and wise political decision-making may also come from sources other than the state, such as individuals and groups with the communicative power and resources to significantly distort public debates. Clearly, Meiklejohn's arguments for free speech are instrumental, rather than intrinsic; he does not value speech or communication for its own sake, but as a means of achieving certain goals namely, the making of informed and wise decisions at election time. ${ }^{72}$ Thus, the connection which Meiklejohn seeks to make between the means (an absence of government restrictions on communication) and the goal (informed and wise voting decisions) is crucial to the success of his argument. However, as I will discuss further below, subsequent scholars, such as Owen Fiss, argue that the values identified by Meiklejohn — promoting informed and wise decisionmaking — actually justify positive government regulation of communication. ${ }^{73}$

Second, although Meiklejohn argues for an individual right to freedom from government restrictions on communication, he argues for this on the basis of the public interest or 'the common needs of all the members of the body politic', rather than based on the individual benefit of particular speakers. ${ }^{74}$ His approach to justifying free speech is therefore a collectivist one, rather than one based purely on individual interests. Meiklejohn in fact criticises arguments for free speech based on the personal interests of the speaker as a form of 'excessive individualism'. ${ }^{75} \mathrm{He}$ asserts that the beneficiaries of free speech are the listeners, or potential listeners, rather than any particular speaker individually. ${ }^{76}$ Thus, Meiklejohn frames free speech as a right to hear, or a right to not be denied

69 Ibid.

70 Ibid 25.

71 Waldron, The Harm in Hate Speech, above n 2, 201-2.

72 Thus, the writer does not agree with Waldron's criticism of Meiklejohn's arguments as 'vague': ibid 182.

73 See, eg, Fiss, above n 26, 18.

74 Meiklejohn, Free Speech and Its Relation to Self-Government, above n 59, 63, 77.

75 Ibid 71

76 Ibid 60. 
access to information and opinions relevant to voting. ${ }^{77}$ However, as I will discuss further below, the assumption that the public always benefits from an absence of restrictions on the dissemination of information and opinions has been subsequently questioned, particularly in relation to the public dissemination of hate speech.

Third, Meiklejohn argues that there should be no restrictions on the exchange of ideas and opinions; he regards free speech as 'absolute'. ${ }^{78}$ Significantly, Meiklejohn's conception of free speech is not limited to discussion of explicitly 'political' ideas and opinions, but includes access to art and literature. According to Meiklejohn, access to art and literature is necessary to develop the character and qualities required for citizens to make an informed voting decision. ${ }^{79}$ Meiklejohn's conception of free speech is unusually broad in that, although it is based on political grounds, it is not limited to protecting only the discussion of topics related to politics and government. ${ }^{80}$ Also, Meiklejohn's argument that access to art and literature is necessary in order to make informed voting decisions is not particularly convincing. Certainly, reading certain novels and poetry may assist in developing a person's skills of critical analysis, and even their moral standing. However, it is difficult to see how unrestricted access to all popular films, for example, assists citizens in making informed and wise electoral decisions. ${ }^{81}$

Meiklejohn did not directly consider the democratic legitimacy of laws regulating racial vilification. However, his general position that there should be no restrictions on the circulation of ideas and opinions in a self-governing democracy would, prima facie, run counter to restrictions on racial vilification. ${ }^{82}$ Assuming that Meiklejohn's arguments would not support restrictions on racial vilification, this article will now consider an analysis of free speech which builds on Meiklejohn's political arguments, but which lends supports to such restrictions.

78 See generally Alexander Meiklejohn, 'The First Amendment Is an Absolute' [1961] Supreme Court Review 245.

79 Ibid 257.

80 Compare this approach to, eg, Meagher, above $\mathrm{n}$ 3, which accepts that free speech arguments based on political grounds are limited to protecting discussion of politics and government.

81 Also, Meiklejohn concedes that the provision of a certain level of education is necessary for citizens to be able to develop and choose informed views: Meiklejohn, 'The First Amendment Is an Absolute', above $\mathrm{n} 78,257$. Therefore, mere access to art and literature, by itself, is not a sufficient condition for wise and informed decision-making.

82 However, Meiklejohn's emphasis on the importance of informed decision-making in a democracy may actually support restrictions on racially vilifying speech. It may be argued that such speech is either irrelevant to informed decision-making, or is positively inimical to this value, as it promotes falsehoods rather than accurate information. These arguments are elaborated further in Part IV(C) of this article, which examines racial vilification and the value of inquiry. 


\section{A Rejoinder to Meiklejohn: The Importance of Preventing Private Obstructions to Political Agency}

Owen Fiss presents an account of free speech which is based on political considerations, but which differs significantly from that of Alexander Meiklejohn. Importantly, Fiss' account of free speech allows for regulation of certain speech acts in certain circumstances, as he argues that this is consistent with the underlying values of free speech..$^{83}$

Whereas Meiklejohn limited the significance of discourse between citizens to voting decisions, Fiss argues that speech (or, more particularly, certain types of speech) are important for public decision-making more generally. Fiss particularly emphasises the importance of ensuring that every citizen has access to, and is not prevented from contributing to, debate on public issues. ${ }^{84}$ Like Meiklejohn, Fiss argues that self-government ultimately requires that the people as a whole determine public policy, by judging the merits of various ideas and proposals. ${ }^{85}$ Fiss also agrees with Meiklejohn that free speech exists, ultimately, to benefit society, rather than any particular individual. Both regard free speech as primarily serving the interests of the audience, or those who receive information and the views of others, rather than the individual interests of particular speakers. ${ }^{86}$

Significantly, however, Fiss challenges Meiklejohn's assumption that the state is necessarily inimical to freedom, and the distrust of government on which purely negative conceptions of free speech are based. ${ }^{87} \mathrm{He}$ argues that the state can actually promote the values underlying free speech (such as democracy and political participation more broadly) by regulating speech (or communication) in certain circumstances. Fiss considers that, in modern society, private aggregations of power are a greater danger to individual freedom than state power. ${ }^{88}$ Therefore, in modern circumstances, state regulation of speech is justified and necessary to counteract the effects of private power. ${ }^{89}$

Fiss argues that modern concepts of democracy involve a positive role for the state, including promoting the equal worth of all citizens and working to eliminate racial discrimination. ${ }^{90} \mathrm{He}$ contends that hate speech 'denigrates the value and worth of its [individual] victims and the groups to which they belong'. ${ }^{91}$ Based on 'the depth of [its] commitment to equality', the state is justified in regulating discriminatory conduct by private individuals. ${ }^{22}$ Fiss argues that hate speech makes it 'impossible for ... disadvantaged groups ... to participate' in public 
debate and to have their views heard.$^{93}$ This is because victims of vilification are either too afraid to participate in public discussion of issues, or because (as a result of vilification) their views 'lack authority' in the eyes of other members of society. ${ }^{94}$ In Fiss' view, it is entirely consistent with free speech to regulate certain conduct, such as racially vilifying speech, which effectively silences its victims. ${ }^{95}$ The purpose of free speech, Fiss argues, is to ensure an open, free and robust debate, which involves ensuring that no voices are silenced, and that every person can participate fully in public discourse. ${ }^{96}$

Fiss maintains that racial vilification by private individuals can skew debate on public issues and silence individuals just as effectively as state regulation. ${ }^{97} \mathrm{He}$ argues that this is against the public interest, because the public is prevented from hearing the contribution of these individuals and groups. ${ }^{98}$ Also, the excluded individuals and groups, as part of the public, are prevented from contributing. Responding to the common contention that the best response to 'bad speech' is more speech, Fiss argues that the silencing (and intimidating) effect of vilification makes this response '[ring] hollow'. ${ }^{99}$ Rather than seeing regulation of vilifying speech as dangerous, Fiss contends that regulation may in fact enhance the values underlying free speech. ${ }^{100}$

Fiss acknowledges the close connection between free speech and equality, and the historical importance of free speech in the movement towards formal racial equality, particularly in the United States. He acknowledges, in particular, the significance of legal protections for the civil rights protests in the United States in the 1960s. ${ }^{101}$ For Fiss, regulating racial vilification is not so much about choosing between two 'ultimate values' - liberty or equality. ${ }^{102}$ Rather, he argues that speech cannot be free without everyone being able to contribute to public debates. According to Fiss, public debate is so important that it must be regulated by rules, to ensure that all sides can be heard. ${ }^{103} \mathrm{He}$ sees this as similar to rules of order, which regulate debates in Parliament. ${ }^{104}$ This is also similar to Meiklejohn's view, which saw public debate as being like a large town meeting, which is regulated by rules of order to ensure that its business was conducted effectively and efficiently.

In summary, Fiss' account of free speech seems to comfortably support laws regulating racial vilification. Such laws are necessary to ensure that people subject to racial vilification are not prevented by such conduct from participating in public debate, and that the general public is not prevented from hearing their views.

93 Ibid 16.

94 Ibid. See also the comments of Gleeson CJ in Coleman v Power (2004) 220 CLR 1, 26 [15].

95 Fiss enigmatically describes this as 'lower[ing] the voices of some in order to hear the voices of others': Fiss, above n 26, 18.

96 Ibid $4,15,83$.

97 Ibid 17.

98 Ibid 21.

99 Ibid 16.

100 Ibid 15,83 .

101 Ibid 11-12.

102 Ibid 13.

103 Ibid 21-2.

104 Ibid. 


\section{Are Racial Vilification Laws Inconsistent with Democratic Values?}

Notwithstanding Fiss' contention that the goal of promoting public participation in political decision-making in fact supports restrictions on hate speech, other commentators argue that such restrictions are inconsistent with the democratic values underlying free speech. This Part examines the arguments recently made in this regard by Ronald Dworkin and Robert Post, and it draws some preliminary conclusions regarding these arguments. Although the conclusions reached by these authors are not ultimately accepted, analysis of these arguments helps to clarify the democratic values at stake in seeking to justify laws regulating racial vilification.

Robert Post's conception of free speech is based, at least partly, on notions of democratic self-government. ${ }^{105}$ However, for Post, the significance of 'selfgovernment' is the ability of individual citizens to participate in the formation of public opinion, rather than the importance of collective decision-making per se. ${ }^{106}$ This enables Post to disavow the connection (which is made, in particular, by Meiklejohn) between self-government and informed decision-making. ${ }^{107}$ Post's account of self-government focuses particularly on the 'relationship between persons and their government', ${ }^{108}$ and the right of individuals to participate in 'public discourse', or the formation of public opinion. ${ }^{109}$ Post's account therefore explicitly prioritises the 'right of speakers to convey ... information', rather than the interests of the audience. ${ }^{110}$

Post's account of free speech particularly emphasises the autonomy of the speaker, and the importance of protecting individual autonomy from the firm grip of the bureaucratic state. ${ }^{111}$ According to Post, the 'fundamental purpose' of free speech is to ensure that government is responsive and accountable to public opinion. ${ }^{112}$ Post's account therefore emphasises the 'self' in self-government, rather than any collective interest in good government. ${ }^{113}$ Whereas Meiklejohn regarded 'self-government' as involving no distinction between the state and the public, Post draws a strong distinction between citizens, on the one hand, and their government, on the other. Further, Post's account is based on a strong distrust of state power, and an emphasis on the importance of individual interests and, in particular, speakers' interests. ${ }^{114}$ It is notable that Post does not seem to

105 Robert Post, 'Participatory Democracy and Free Speech' (2011) 97 Virginia Law Review 477, 482.

106 Ibid.

107 Ibid.

108 Ibid.

109 Ibid 482-4.

110 Ibid $482,486$.

111 Ibid 488 .

112 Ibid 487.

113 It is noted that emphasising the autonomy of the speaker is more typical of free speech arguments based on the values of personal dignity and autonomy (which are examined in Part IV(B) of this article), rather than political arguments.

114 See generally Post, 'Participatory Democracy and Free Speech', above n 105. 
acknowledge the important contributions made by Fiss to the free speech debate. In particular, Post does not acknowledge that private actors can prevent individuals from participating in public discourse just as effectively as can government regulation. Post seems to assume that an absence of laws limiting participation in public discourse is sufficient to ensure equal participation. ${ }^{115}$ This is a serious weakness in his account of free speech, particularly given the emphasis he places on the importance of open and equal access to public discourse.

The above paragraphs outline Post's general position regarding freedom of speech. More recently, however, Post has offered specific criticisms of laws regulating racial vilification in particular. He has argued that such laws seek to enforce 'civility norms' regarding speech, and that this involves impermissible state regulation of 'public discourse'. ${ }^{116}$ Post regards regulation of public discourse by the state as inconsistent with democracy and self-determination, or the notion that citizens decide matters collectively, without interference by the state. ${ }^{117} \mathrm{He}$ argues that 'the objective of public discourse is to determine what our purposes are', ${ }^{118}$ and that these purposes must 'perennially be taken as provisional and revisable'. ${ }^{119}$

Post regards 'civility rules' (which, for him, include hate speech laws) as particularly inappropriate in relation to regulating public discourse. Such rules, he argues, inevitably reflect the values of the dominant social group, and are used to privilege those values and to protect them from challenge. ${ }^{120}$ He argues that hate speech laws potentially exclude certain groups from participating in public discourse. ${ }^{121}$ According to Post, this is inconsistent with the open and equal access to public discourse which is central to the legitimacy of public decisionmaking and the values of self-government. ${ }^{122}$ It is notable that Post does not clearly specify which groups he claims are excluded by hate speech laws. Post also seems to ignore Fiss' point that hate speech, itself, can be exclusory. At times he refers generally to 'diverse communities' and 'multiculturalism'. ${ }^{23}$ At other times he argues that hate speech laws which emphasise a speaker's manner of expression seem to benefit the 'educated man' and punish the 'uneducated', ${ }^{124}$ as they punish only 'crude expression'. ${ }^{25}$ Although his arguments are not clearly articulated, the contention that racial vilification laws exclude certain groups or speakers from public debate is serious and needs to be addressed.

115 Ibid 484-5.

116 As mentioned above, 'public discourse' is, for Post, the process by which public opinion is formed: ibid 482-4.

117 Robert Post, 'Hate Speech' in Ivan Hare and James Weinstein (eds), Extreme Speech and Democracy (Oxford University Press, 2009) 123, 130.

118 Molnar, above n 47, 14.

119 Ibid.

120 Post, 'Hate Speech', above n 117, 132.

121 Ibid 136.

122 Ibid 133.

123 Molnar, above n 47, 17.

124 Post, 'Hate Speech', above n 117, 131, quoting United Kingdom, Parliamentary Debates, House of Commons, 24 January 1930, vol 234, col 535 (Kingsley Griffith).

125 Post, 'Hate Speech', above n 117, 135. 
Post's argument that hate speech laws exclude certain groups from participating in public debate seems to ignore the important distinction between, on the one hand, a speaker, and, on the other, the attitudes and opinions which they express. Hate speech laws (including racial vilification laws) do not actually prohibit certain people or groups from speaking - they only prohibit certain forms of hateful expression. ${ }^{126}$ Therefore, Post's argument that certain groups are excluded from public debate by hate speech laws seems overstated.

Post's argument that rules pertaining to public debate should allow for discussion of fundamental and controversial issues is well made. However, hate speech laws do not prevent such discussion. Racial vilification laws merely prohibit extreme and harmful forms of vilification. ${ }^{127}$ Further, Post seems to assume that vilifying speech always conveys a 'political' message. However, some types of vilification are simply direct abuse of a person or group. ${ }^{128}$ Post's argument that the primary purpose of free speech is simply to protect the formation of 'public opinion', ${ }^{129}$ rather than the making of public decisions, is also questionable. The purpose of government is to make decisions and, therefore, the fundamental purpose of selfgovernment is, as Meiklejohn stated, the making of public decisions. ${ }^{130}$ Vilifying speech can be seen as a form of individual or collective abuse, and therefore as a disruption to public decision-making, rather than a positive contribution to it. Post's assertion that hate speech laws impose an 'undemocratic' burden on the public decision-making process therefore should not be accepted. ${ }^{131}$

Ronald Dworkin has mounted a similar attack on hate speech laws. Dworkin argues that racial vilification laws prevent people who oppose certain laws and policies (in particular, anti-discrimination laws and affirmative action policies) from publicly expressing their opposition to those laws and policies. ${ }^{132}$ According to Dworkin, this undermines the democratic legitimacy of those laws. ${ }^{133}$ For Dworkin, it is essential 'that each citizen have not just a vote but a voice', ${ }^{134}$ and that 'everyone has ... a fair opportunity to express his or her attitudes or opinions or fears or tastes or presuppositions or prejudices or ideals'. ${ }^{135}$ According to Dworkin, this is necessary 'to confirm his or her standing as a responsible

126 Waldron, The Harm in Hate Speech, above n 2, 187. Vilification laws may prevent people from making racist comments that are very important to them. However, as will be discussed below, the main issue is the democratic implications of these restrictions.

127 See, eg, RDA s 18D, which provides broad exemptions to s 18C. See also ibid 183.

128 See below Part IV(B)(3).

129 Post, 'Participatory Democracy and Free Speech', above n 105, 482.

130 Meiklejohn, Free Speech and Its Relation to Self-Government, above n 59, 25.

131 It is also noted that hate speech legislation can be modified or repealed in the usual way, and that almost all democratic countries have chosen to enact such laws.

132 Ronald Dworkin, 'Foreword' in Ivan Hare and James Weinstein (eds), Extreme Speech and Democracy (Oxford University Press, 2009) v, viii. See also Ronald Dworkin, 'Reply to Jeremy Waldron' in Michael Herz and Peter Molnar (eds), The Content and Context of Hate Speech: Rethinking Regulation and Responses (Cambridge University Press, 2012) 341.

133 Dworkin, 'Foreword', above n 132, viii.

134 Ibid vii.

135 Ibid. 
agent in, rather than a passive victim of, collective action'. ${ }^{136}$ He argues that ' $[t]$ he majority has no right to impose its will on someone who is forbidden to raise a voice in protest or argument or objection' to certain laws or policies. ${ }^{137}$ Dworkin states that it is illegitimate for the state to 'silence' any citizen in this way, or to prevent them from presenting their attitudes or prejudices. ${ }^{138} \mathrm{He}$ asserts that 'in a democracy no one ... can have a right not to be insulted or offended' ${ }^{139}$

It is notable that Dworkin equates free speech with an individual right, in fact 'a universal human right'. ${ }^{140}$ Whereas Meiklejohn and Fiss base their arguments on the interests of the listener or potential audience, Dworkin is primarily concerned with the interests of the individual speaker. He frames the speaker as the 'victim' of 'the coercive powers of the state' and of 'the majority's will'. ${ }^{141}$ Further, Dworkin claims that the harms attributed to 'bad speech' such as racial vilification are 'inflated and ... absurd'. ${ }^{142}$

Like Post, Dworkin frames racially vilifying speech as, at least potentially, a contribution to political discussion. He adopts a very broad definition of 'political discourse', which includes every expression of a person's 'attitudes or opinions or fears or tastes or presuppositions or prejudices or ideals'. ${ }^{143}$ These expressions are regarded as contributions to the formation of public opinion, on an equal footing with formal political statements and writing. ${ }^{144}$ Because Dworkin's conception of free speech is based on individual dignity rather than informed decisionmaking, ${ }^{145}$ he argues that it protects from regulation not only the substantive message or attitude sought to be expressed, but also the tone or language used. He argues that how an individual chooses to express their views is part of exercising their autonomy as a speaker, and therefore hate speech should be immune from regulation, no matter how hatefully it is expressed. ${ }^{146}$ Dworkin argues that racial vilification is 'political', because it is actually a protest or expression of opposition to certain law and policies, such as anti-discrimination or affirmative action. ${ }^{147}$ Dworkin acknowledges the importance of equality and laws which support this value. ${ }^{148}$ However, he argues that the state actually affirms principles of equality by not preventing any person from voicing their attitudes or opinions - no matter how 'offensive' the 'majority' finds those attitudes or opinions. ${ }^{149}$

136 Ibid.

137 Ibid.

138 Ibid ix. Dworkin regards free speech as a 'universal human right' based on human dignity, rather than being based on democratic values. This view will be discussed further in Part IV(A)(4) of this article.

139 Dworkin, 'Foreword', above n 132, viii.

140 Ibid ix.

141 Ibid vii.

142 Ibid vi.

143 Ibid vii.

144 Ibid viii.

145 Ibid vii.

146 Ibid viii.

147 Ibid vi.

148 Ibid viii.

149 Ibid viii. 
Dworkin's arguments have many of the same weaknesses as those of Robert Post, which have been examined above. Contrary to Dworkin's arguments, hate speech laws do not prevent the expression of opposition to anti-discrimination laws, or any other laws, provided the opposition is expressed reasonably moderately. ${ }^{150}$ Dworkin correctly observes that hate speech laws potentially exclude certain 'extreme' forms of expression from public debate. ${ }^{151}$ The issue, however, is the democratic implications of this exclusion. Jeremy Waldron has argued that hate speech laws in fact support democratic values, rather than being inconsistent with them, as they protect the dignity and equal standing of vulnerable members of society, and they promote racial equality. ${ }^{152}$ Waldron emphasises the harms of 'extreme' hate speech, to individual victims and to society. ${ }^{153}$ Like Meiklejohn and Fiss, Waldron bases his arguments on the interests of society — an approach which is expressly rejected by Dworkin. ${ }^{154}$ Waldron argues that the harms of allowing extreme hate speech outweigh the possible social benefits. ${ }^{155}$ Dworkin, on the other hand, argues that such harms are overstated, or argues that they are irrelevant to justifying hate speech laws. ${ }^{156}$

Dworkin and Waldron base their respective arguments on two very different conceptions of democracy. Dworkin regards it as unfair, or even illegitimate, to exclude even extreme racist views and attitudes from public debate. By contrast, Waldron emphasises the harms of such views to those targeted by hate speech. Waldron describes these individuals and groups as 'vulnerable minorities', and emphasises the extent to which their ability to live a decent life depends on other members of society respecting their fundamental human dignity. ${ }^{157}$ Dworkin, on the other hand, emphasises the unfairness of speakers being 'silenced' by hate speech laws based on 'how offensive the majority takes these convictions or tastes or prejudices to be'. ${ }^{158}$ At a fundamental level, these views are irreconcilable. However, Waldron's arguments seem more persuasive, in that he notes the already disadvantaged situation of many members of racial and ethnic minorities, and their need for legal protection from serious harm. This is supported by Fiss' observation that hate speech can effectively exclude minorities from public debate. Dworkin argues that silenced speakers are the real victims of hate speech laws. He does not seem to acknowledge that hate speech, itself, can effectively silence members of minorities. Nor does he present credible arguments as to why extreme hate speech is valuable to the wider community, particularly regarding political decision-making.

Waldron, The Harm in Hate Speech, above n 2, 182-3.

151 Dworkin, 'Foreword', above n 132, vi. See also ibid 189-90.

152 Waldron, The Harm in Hate Speech, above n 2, 203.

153 Ibid 194.

154 Dworkin, 'Foreword', above n 132, v.

155 Waldron, The Harm in Hate Speech, above n 2, 196.

156 Dworkin, 'Foreword', above n 132, vi. The harms of hate speech, which can fairly be described as significant, are discussed in Part IV(B)(3) of this article.

157 Waldron, The Harm in Hate Speech, above n 2, 196-7.

158 Dworkin, 'Foreword', above n 132, viii (emphasis added). 


\section{Democratic Arguments for Free Speech Are Consistent with Racial Vilification Laws}

In summary, this Part has argued that racial vilification laws are consistent with democratic values, including the importance of public participation in collective decision-making. Racial vilification can severely restrict individuals and groups from participating in public debate, in several ways. First, individuals and groups victimised by racial vilification may be too intimidated, traumatised, frightened or undermined by vilifying comments to participate in public discussions at all, and, in particular, in discussions involving racial issues. ${ }^{159}$ Second, vilifying comments are a form of group defamation, which may cause other members of society to look down on members of certain racial groups, ${ }^{160}$ and potentially, to discount their views. Thus, members of certain racial groups may effectively be silenced by vilifying conduct. To the extent that racial vilification laws operate to limit the incidence and effects of racial vilification, such laws may play an important role in enabling members of minority groups to participate in democratic processes.

Although Post and Dworkin argue that certain speakers are 'silenced' by hate speech laws, several points should be noted in this regard. As Waldron notes, hate speech laws are primarily focused on restricting certain extreme forms of expression, such as abusive, insulting and threatening messages. ${ }^{161}$ As such, very few genuine political contributions are caught by such laws. ${ }^{162}$ Also, as noted above, racially vilifying speech can itself exclude certain individuals and groups from participation in public debate. Victims of racial vilification typically face various forms of disadvantage and exclusion. The state therefore has an interest and an obligation to ensure these individuals and groups can contribute to public debate, particularly regarding issues that affect them personally. ${ }^{163}$ In summary, racial vilification laws are supported by, and not inconsistent with, democratic values (including those underlying free speech).

\section{B Arguments Based on Dignity and Autonomy}

This Part examines a second group of arguments for free speech, which are based on the personal and interpersonal importance of speech. Certain types of speech — including, potentially, racial vilification - are said to promote important values such as self-fulfilment and the full development of an individual's personality. ${ }^{164}$ The nurturing of each individual's potential is said, in turn, to benefit society. ${ }^{165}$ It is also contended that unfettered communication is essential

159 Fiss, above n 26, 15-18.

160 Waldron, The Harm in Hate Speech, above n 2, 34-64.

161 Ibid.

162 Ibid 182-3, 190.

163 Chesterman, above n 3, 195.

164 See below Part IV(B)(1).

165 Ibid. 
to the formation and nurturing of interpersonal relationships, which are goods in themselves. ${ }^{166}$ On the other hand, many commentators argue that racial vilification causes serious personal harms, including long-term psychological harm, to its victims. ${ }^{167}$ This can cause victims to withdraw from employment, education and social engagement. ${ }^{168}$ The extent and seriousness of these harms to vulnerable minorities is said to justify laws regulating racial vilification, notwithstanding the personal and interpersonal benefits that might accrue to certain people, were they permitted to racially vilify others. ${ }^{169}$

This Part will first examine the arguments of John Stuart Mill, an early and powerful proponent of the personal importance of free speech. It will then examine the arguments of Thomas Nagel, Thomas Scanlon and C Edwin Baker, who present more modern conceptions of free speech. These conceptions emphasise the speech rights of individuals, often in opposition to collective interests, which would favour regulation of speech. The harms of racial vilification will then be discussed. First, arguments that racial vilification causes serious harm to individuals and to racially diverse communities will be examined. Second, the concept of 'harm' will be considered, including different conceptions of harm, and arguments that only certain types of harm are relevant to regulating speech. Specifically, this Part will examine whether 'offensiveness' is sufficient grounds for regulating speech, and whether racial vilification can be considered seriously offensive. ${ }^{170}$ Third, this Part will examine arguments that speech may be regulated on the grounds of protecting individual dignity, and the arguments of Jeremy Waldron that racial vilification may be regulated on these grounds will be addressed. Finally, this Part will weigh the benefits of free speech against the harms of racial vilification to determine whether regulating the latter is justifiable on personal and interpersonal grounds.

\section{John Stuart Mill and the Personal Importance of Free Speech}

One of the most famous proponents of free speech, John Stuart Mill, based his arguments in favour of free speech on the role of speech in the full development of the human character and personality. ${ }^{171}$ 'Speech', in this context, refers to the process of communicating with others, rather than merely the individual act of speaking. ${ }^{172}$ Mill argued that the process of expressing ideas and opinions, and of hearing and considering the ideas and opinions of others, is essential to the full development of the human personality. ${ }^{173}$ Mill maintained that speech enables

166 See below Part IV(B)(2).

167 See below Part IV(B)(3).

168 Ibid.

169 See below Part IV(B)(7).

170 The significance of 'serious' offence is outlined in Part IV(B)(5) of this article.

171 See generally John Stuart Mill, 'On Liberty' in Alan Ryan (ed), Mill: Texts, Commentaries (W W Norton, revised ed, 1997) 52.

172 Schauer, above n 2, 54.

173 Mill, above n 171, 56. 
an individual to flourish on all levels — intellectual, emotional, and moral. ${ }^{174} \mathrm{He}$ argued that the process of discussing ideas and opinions exercises and develops the human faculties of reason and emotion. ${ }^{175}$ Specifically, Mill argued that individuals develop to their full potential by exposure to the opinions of 'wise ... individuals', such as Socrates and Christ. ${ }^{176}$ By being exposed to 'the best men [sic] and the noblest doctrines', ${ }^{177}$ ordinary individuals would themselves develop fully. Like Meiklejohn and other proponents of free speech, Mill particularly emphasised the benefits for the listener, rather than the speaker, in the unrestricted dissemination of ideas and opinions. ${ }^{178} \mathrm{He}$ argued that restrictions on speech are not merely a "private injury"179 to the speaker, but are detrimental to all those who would otherwise hear the speaker's ideas or opinions. He argued that the general public benefits from hearing all possible ideas and opinions on a given issue, and the public will be harmed if speech is restricted. ${ }^{180}$ Consistently with modern understandings of free speech, Mill argued that the ability of people to seek and to receive information is just as important as a speaker's ability to speak. ${ }^{181}$

Mill's argument for free speech is based on powerful notions of the importance of human development and social progress. Importantly, Mill did not argue for unrestricted speech on all matters. Because of his emphasis on human development, he was particularly concerned that discussion of 'the highest subjects', ${ }^{182}$ 'the greatest questions ${ }^{\text {'183 }}$ and 'large and important ${ }^{\text {'184 }}$ issues not be restricted. Mill was not so much arguing for unrestricted speech for its own sake, as he was seeking to prevent ignorance, mediocrity, and slavish acceptance of official dogma and 'received opinion'. ${ }^{185}$ Mill's arguments are based on particular historical incidents and famous historical figures. Mill pointed to several instances where 'the best men [sic]'186 — whom society should listen to - were persecuted, and their views suppressed, to the great detriment of society. ${ }^{187}$ Mill emphasised the important role of dissenters and critics of received opinion, who publicly challenge orthodox views and conventional modes of thought. ${ }^{188}$ Mill thus drew a strong connection between individuals with dissenting views, and the benefit to society of not silencing these views. 
It should also be noted that Mill was not concerned exclusively (or even primarily) with the effect of laws and other forms of formal regulation on speech; he argued that public opinion 'is as efficacious as law' 189 in silencing those who dissent from received opinion. In fact, Mill emphasised the negative effects of social stigma on an individual's ability to communicate, and he argued strongly for public toleration of those with unconventional views. Mill drew a strong contrast between, on the one hand, the situation of the lone dissenter, who was 'fearless', ${ }^{190}$ unconventional and courageous, and, on the other hand, the ordinary public, which consisted of 'a few wise and many foolish individuals'. ${ }^{191}$ He argued that members of the public, due to their fear and ignorance, are often and easily driven to persecute the 'few wise ... individuals', ${ }^{192}$ and 'that truth would lose something by their silence'. ${ }^{193}$ The relationship between ordinary members of the public, on one hand, and gifted individuals, on the other, is one of the main pillars of Mill's conception of free speech. ${ }^{194}$

In emphasising the supposed benefits of free speech, Mill barely acknowledged the harms which speech can cause. ${ }^{195}$ He seemed to assume that the only, or main, harm was in the restriction of speech (either by laws, or by public opinion), which he described negatively as censoring or 'suppression'. ${ }^{196}$ In his writing, Mill referred repeatedly to speech as 'opinions', ${ }^{197}$ this emphasised the positive role of speech in the dissemination of ideas. Mill focused on the potential harm done by the suppression of ideas, and he generally ignored any harm done by the act of expression itself. However, proper recognition of the harm caused by certain speech acts is central to the discussion of the regulation of racial vilification. ${ }^{198}$

Although racial vilification laws did not exist at the time when Mill was writing, it is arguable that his general approach to free speech does not run counter to such laws, and may in fact support them. As outlined above, Mill's conception of free speech sought to protect and promote discussion of "the highest subjects"199 or the 'large and important' questions. ${ }^{200}$ Arguably, this does not include the types of

189 Ibid 65.

190 Ibid 66.

191 Ibid 56.

192 Ibid.

193 Ibid 78.

194 Mill was also concerned by the ability of powerful institutions, such as the established church, to persecute people who questioned their doctrines and teachings. This topic is examined further in Part IV(C) of the article.

195 Mill's reference to the dangers of inciting a group of people to hatred of a person, in the immediate vicinity of that person, is a rare exception: Mill, above $\mathrm{n} 171,84$.

196 Ibid 81. It should be noted that regulating certain forms of communication does not necessarily prevent that communication in a practical sense - it merely attaches a cost to it. Thus, speech is never truly 'supressed', it is merely penalised. There are important practical differences, therefore, between preventing the distribution of a book (the classic form of 'censorship'), and attaching civil and criminal penalties to publishing certain words. In the second case, the words may still be uttered, and may enter circulation, although the speaker may be penalised in some way.

197 Ibid.

198 See generally Waldron, The Harm in Hate Speech, above n 2.

199 Mill, above n 171, 66.

200 Ibid 67. 
racial abuse, humiliation and intimidation that are targeted by hate speech laws. Also, although Mill sought to protect unpopular individuals, it is also arguable that the 'minorities' which deserve protection are in fact racial minorities, rather than the individual speakers (who often have significant power and standing in society) who seek to vilify them. ${ }^{201}$

As described above, Mill's support for free speech is based on the developmental potential of speech and dialogue for individuals, and the flow-on benefits for society. In short, Mill seeks to promote individual capacity and potential. However, as will be outlined below, certain types of speech — including racial vilification - can damage individuals in ways which seriously limit, or even prevent, their full human development.

\section{The Modern Debate: Free Speech, Autonomy and Dignity}

Mill's conception of free speech, although based on the developmental benefits of the free exchange of ideas, generally emphasises the collective benefits to society of unrestricted discussion. However, modern proponents of the personal benefits of speech, such as Thomas Nagel, Thomas Scanlon and C Edwin Baker, base their arguments explicitly on values associated with individualism. This Part will examine the arguments of these authors, particularly as they relate to the regulation of racial vilification.

Many modern free speech proponents base their arguments on principles such as human dignity and the importance of preserving individual autonomy. Thomas Scanlon, for example, is critical of free speech arguments based on the value of democracy. He argues that democracy is merely an institutional arrangement, which is not a firm basis for an individual right. ${ }^{202}$ Of course, democracy (including universal suffrage) is not embraced in every country, and is a relatively recent development even in Western countries. Like many modern free speech proponents, Scanlon asserts an individual right to free speech, based on universal values. ${ }^{203} \mathrm{He}$ argues that the value of human autonomy, rather than democracy, is the proper basis for free speech protection. ${ }^{204} \mathrm{He}$ argues that autonomy is a more basic and universal moral value than is democracy. By contrast, he claims that free speech theories based on democracy are 'artificial'. ${ }^{205}$

For Scanlon, a person is autonomous if they are 'sovereign in deciding what to believe and in weighing competing reasons for action'. ${ }^{206}$ Scanlon's account of free speech, like Post's, is based on a clear division between the individual and the state, and, particularly, on preventing any potential intrusion by the state into

201 The power imbalance which commonly exists between vilifiers and their targets is examined in Part $\operatorname{IV}(\mathrm{B})(3)$ of this article.

202 Thomas Scanlon, 'A Theory of Freedom of Expression' (1972) 1 Philosophy and Public Affairs 204, 205-6.

203 Ibid.

204 Ibid 215-22.

205 Ibid 205.

206 Ibid 215. 
the personal or 'autonomous' realm of the individual. Like Meiklejohn's account of free speech, Scanlon's seeks to limit the regulatory reach of the state. In particular, Scanlon seeks to ensure that citizens are able to influence each other's views, particularly regarding the merits of certain laws and policies, and to ensure that the state does not prevent citizens from influencing each other in this way. ${ }^{207}$ Scanlon's theory is particularly focused on the interests of the listener, rather than the speaker. ${ }^{208}$ He regards it as an interference with a person's autonomy for the state to determine for individuals which ideas and information are dangerous, or even false. ${ }^{209}$ These judgments, he argues, should be made by individuals, rather than by the state. ${ }^{210}$

Thomas Nagel's account of free speech is based on similar grounds to those relied on by Scanlon. His account is based on the 'inviolability' of the individual, which is 'intrinsic' to the human person and which prohibits certain forms of 'interference' by the state. ${ }^{211}$ Such immunity from interference is necessary, Nagel argues, as humans are 'independent thinking being[s]', who have a 'responsibility to make up [their] own mind[s]'. ${ }^{212}$ When the state regulates what ideas and opinions people can hear, it is treating people as if they 'are not trusted to make up [their] own minds', and is engaging in 'thought control'. 213

C Edwin Baker also strongly asserted an argument for free speech based on autonomy. Baker argued that self-expression, through communicative acts such as speech, enables a person to fully express their personality and identity. ${ }^{214}$ For Baker, expressing one's views on various topics enables a person to 'defin[e] who she is and [to express] her view of the world' on her own terms. ${ }^{215}$ Baker regarded a person's opinions as an essential part of their identity and character. He also argued that speech and communication enable a person to form authentic and meaningful human relationships, and that uninhibited self-disclosure (through the expression of one's views and opinions) is particularly important to the formation of intimate human relationships. ${ }^{216}$ According to this view, state censorship of certain opinions may result in individuals not being willing to express deeply held views and opinions, and the formation of relationships, based on these views, may be inhibited. ${ }^{217}$

209 Ibid.

210 Ibid. Scanlon does not seem to consider the possibility of private actors or institutions, such as the media, undermining or distorting people's ability to make such judgments.

211 Nagel, above n 49, 93-4.

212 Ibid 96.

213 Ibid 97. As with Scanlon, Nagel does not seem to consider the role of private actors and institutions in relation to people's capacity to exercise competent judgment.

214 C Edwin Baker, 'Harm, Liberty, and Free Speech' (1997) 70 Southern California Law Review 979, 982-6.

215 Ibid 1019.

216 Ibid.

217 Ibid. 
Baker emphasised that human relationships are commonly based on shared values and common understandings of life, and that these values and understandings can be expressed and known only through various forms of communication. He argued that certain forms of censorship could inhibit this natural and beneficial process of forming relationships, particularly by social pressures resulting from laws regulating certain types of speech. ${ }^{218}$ Baker regarded free speech as an aspect of human dignity - a core part of what it means to be human. In fact, Baker regarded free speech to be absolute; the state cannot regulate speech, even if that speech causes harm. ${ }^{219}$

Whereas Baker's conception of autonomy was explicitly based on the interests of individual speakers, Scanlon and Nagel's accounts are based on the interests of the listening public. Baker's account is therefore extremely individualistic; it is explicitly based on opposition to an approach based on maximising benefits to the public. Baker specifically criticised such approaches as being antithetical to the proper protection of individual rights. ${ }^{220}$ Baker's account is thus similar to that of Mill, who also emphasised the 'unfairness' of society silencing individual speakers. Baker's account is unique, however, in that it emphasises particular individual interests in speech, rather than any collective benefit to society in regulating certain speech.

The arguments presented by Scanlon, Nagel and Baker are persuasive insofar as individual autonomy and dignity are important human values. However, a person's ability to make decisions regarding their own life can be limited in many ways other than by state regulation. Importantly, a person's choices may be limited by the actions of other individuals. For example, racially vilifying speech may cause harms which limit a person's ability to participate fully in society. In this way, regulation of vilifying speech, although it may limit the autonomy of one person, may actually facilitate the autonomy of others. The arguments presented by Scanlon, Nagel and Baker only consider the autonomy of the speaker and the audience. These approaches do not consider the autonomy of those at whom the speech is directed - the 'targets' of hate speech. ${ }^{221}$ The next Part will consider the effects of hate speech on its targets and victims, and the following sections will consider the implications of these harms for the regulation of such speech.

\section{The Actual Harms of Hate Speech}

This Part examines the harms of hate speech — particularly to its victims - and the relationship between these harms and regulation of this type of speech. The starting point for discussion is the important work of critical race theorists Richard

218 Ibid. Mill also noted that social stigma regarding certain topics and views could stifle public debate in the same way as regulation by the state: Mill, above n 171, 65-6.

219 See generally Baker, above n 214. This argument is examined further in Part IV(B)(4) of this article.

220 Ibid 979-81.

221 See generally Waldron, The Harm in Hate Speech, above n 2. In this context, an audience is arguably distinct from a target of hate speech. The difference, as indicated above, is that a target is a member of the group at whom the particular words are directed - the subject of the speech - whereas an audience is not. 
Delgado and Jean Stefancic on the serious harms of hate speech. ${ }^{222}$ Delgado and Stefancic challenge some of the assumptions commonly made regarding hate speech, for example, that it merely causes 'hurt feelings'.

Delgado and Stefancic argue that racial hate speech causes harm to individual victims and to society generally. They focus particularly on 'direct' or face-toface incidents of hate speech, which, they argue, cause immediate and serious psychological and physical harm to their individual targets. ${ }^{223}$ The nature and extent of the harms caused can depend on several factors, such as the status of the speaker, and their relationship to the victim. For example, Delgado and Stefancic argue that hate speech is more harmful when uttered by an employer to an employee, or teacher to a student, or by any person in a position of authority over the target. ${ }^{224}$ Presumably, the harm is greater in these situations because it is more difficult for the victim to avoid the perpetrator, and because the perpetrator has a degree of power over the victim, independently of the hate speech. ${ }^{225}$ Delgado and Stefancic argue that certain victims of hate speech, for example, children, are particularly vulnerable to harm, due to their developing personalities. ${ }^{226}$ However, they argue that all members of racial groups are vulnerable to the harms of hate speech. This is because racial insults concern an unchangeable personal characteristic, and one which is central to the person's identity. ${ }^{227}$ This characteristic is usually also visible and obvious to others. ${ }^{228}$ Delgado and Stefancic argue that members of racial minorities are usually 'the least powerful and most vulnerable members of society'. ${ }^{229}$ Their circumstance of disadvantage often involves extreme poverty and limited economic opportunities. ${ }^{230}$

Delgado and Stefancic argue that the seriousness of hate speech can by fully appreciated when individual incidents are viewed not in isolation, but in light of the entire history of discrimination and violence experienced by a person and group. ${ }^{231}$ They argue that the harms of hate speech must be viewed as the victim experiences them. Particularly, they note that these harms are cumulative, compounding and aggregative on a particular person and group over time. ${ }^{232}$ Consideration of harm must also include consideration of the historical treatment of the particular racial group, for example, where this involves slavery, segregation,

222 See especially Richard Delgado and Jean Stefancic, Understanding Words that Wound (Westview Press, 2004); Richard Delgado and Jean Stefancic, Must We Defend Nazis?: Hate Speech, Pornography, and the New First Amendment (New York University Press, 1997).

223 Delgado and Stefancic, Understanding Words that Wound, above n 222, 12.

224 Ibid, 63-6, 73. See the discussion by Melinda Jones of the prevalence of incidents of racism by police towards Australian Indigenous people, in Melinda Jones, 'Empowering Victims of Racial Hatred by Outlawing Spirit-Murder' (1994) 1 Australian Journal of Human Rights 299, 308.

225 In this situation, the vilification is also more likely to be repeated or regular.

226 Delgado and Stefancic, Understanding Words that Wound, above n 222, 15, 93-9.

227 Ibid 5, 16. It has been argued that a person's race is not always, or invariably, central to their identity: see generally Garton Ash, above n 30 .

228 Delgado and Stefancic, Understanding Words that Wound, above n 222, 21.

229 Ibid 35.

230 Ibid 39.

231 Ibid 16.

232 Ibid 23, 117-18. 
genocide or other forms of oppressive and dehumanising treatment. ${ }^{233}$ Delgado and Stefancic argue that there is a strong connection between hate speech and such forms of treatment, in that speech by which particular races are 'demonized, marginalized, stereotyped, reviled, and excluded' encourages and provokes such treatment. ${ }^{234}$ For Delgado and Stefancic, the personal and societal harms of hate speech are closely connected. On a personal level, hate speech causes individual victims to suffer stress and depression, and to perform poorly in, and to avoid, situations where they are likely to experience further abuse - such as school, university and the workplace. ${ }^{235}$ On a societal level, hate speech runs contrary to the equal worth and individual dignity of each member of society. ${ }^{236}$ These are fundamental values in a democratic society based on multiculturalism. ${ }^{237}$ Hate speech marginalises its victims, and establishes a class system, under which certain groups are not regarded as entitled to equal rights, and their dignity is not respected. ${ }^{238}$ Hate speech also promotes animosity and conflict, rather than harmony, between different racial groups. ${ }^{239}$

Delgado and Stefancic argue that hate speech is racism in verbal form. It is a powerful means by which racial groups are stigmatised, and their inferior status is reinforced. ${ }^{240}$ Hate speech is used by dominant groups to maintain power and control over members of less powerful groups. ${ }^{241}$ Such speech powerfully shapes perceptions of particular people and groups, and assists in presenting oppressive treatment and unequal social relationships as 'normal'. ${ }^{242}$

\section{Harm and Regulation of Hate Speech}

This Part examines the relationship between the harms of hate speech (as outlined above), and its regulation. In particular, it examines the views of John Stuart Mill and $\mathrm{C}$ Edwin Baker regarding the relevance of harm to the regulation of speech. In summary, Mill argues that harm to others is a proper basis for regulating speech acts. ${ }^{243}$ On the other hand, Baker argues that harm is not a proper basis for regulating speech, as free speech is an individual right which is not subject to limitation on the grounds that it will benefit the public generally. This Part examines the views of Mill and Baker regarding the significance of harm in relation to justifying regulation of hate speech. It does not specifically consider the views of Scanlon and Nagel, as neither author addressed this issue in 
particular. In any case, the views of Scanlon and Nagel are sufficiently similar to those of Baker to negate the need for separate consideration.

In On Liberty, Mill declared that speech could be limited only if it caused 'harm to others'. ${ }^{244}$ This is based on the classical liberal value of maximising individual freedom by limiting legal regulation. Particularly, the threshold of 'harm to others' seeks to prevent paternalistic laws. ${ }^{245}$ The concept of 'harm', however, is very broad, ranging from serious physical harm, at one end, to mere emotional upset, at the other. Mill clearly regarded the possibility of serious physical harm as sufficient justification for limiting a person's freedom to speak. ${ }^{246}$ Equally clear, however, was his scepticism as to whether psychological or emotional harm would justify limiting speech. ${ }^{247}$ It is common to characterise the harms caused by hate speech as mere 'hurt feelings', which strongly suggests that limitation of such speech is not justified. ${ }^{248}$ However, as noted by Delgado and Stefancic, the harms of hate speech can be far more serious, and include serious psychological harm and chronic health effects, such as anxiety and depression. ${ }^{249}$ Mari Matsuda argues that the harms of hate speech are not borne by the community at large, but are 'imposed on those least able to pay'. ${ }^{250}$ These types of harms may justify regulating hate speech according to the 'harm' standard set down by Mill.

Also, given Mill's emphasis on the importance of the development of the human personality, an additional reason for restricting hate speech is that such speech can undermine that development (for the listener). As highlighted by Delgado and Stefancic, hate speech can deter its victims from continuing their education, ${ }^{251}$ which can stifle their opportunities in terms of employment and full participation in society. Hate speech can also cause its victims to experience anxiety as they go about ordinary activities, such as work, study and social activities.

Although it is generally accepted that potential serious harm is a sufficient basis for restricting certain speech, ${ }^{252}$ Baker argues that, by itself, harm does not justify such limitations. ${ }^{253}$ As discussed above, Baker regards free speech as an individual right, inhering in the speaker, which is not subject to limitations based on utilitarian grounds. Free speech, according to Baker, is based on human

244 Mill, above n 171, 84.

245 Garton Ash, above n 30, 218.

246 This is shown by the example Mill provided of speech inciting an already excited crowd gathered outside the house of a corn dealer: Mill, above n 171, 84 .

247 See Jeremy Waldron, Liberal Rights: Collected Papers 1981-1991 (Cambridge University Press, 1993) 115-33.

248 See, eg, Baker, above n 214, 1007-8.

249 Delgado and Stefancic, Understanding Words that Wound, above n 222, 12. See also Charles R Lawrence III, 'If He Hollers Let Him Go: Regulating Racist Speech on Campus' [1990] Duke Law Journal 431, 462. Of course, not all instances of hate speech will have such a severe impact. However, because of the seriousness of the potential harm, restrictions on such speech are justified.

250 Mari J Matsuda, 'Public Response to Racist Speech: Considering the Victim's Story' (1989) 87 Michigan Law Review 2320, 2323.

251 See above Part IV(B)(3).

252 See, eg, L W Sumner, The Hateful and the Obscene: Studies in the Limits of Free Expression (University of Toronto Press, 2004) 41-5.

253 See generally Baker, above n 214. 
autonomy, rather than on the importance of democracy or any other 'instrumental' justification. ${ }^{254} \mathrm{He}$ argues that, because the importance of free speech is based on the value of autonomy, speech cannot be limited on the grounds that the public would benefit from such limits. Human autonomy is said to be an 'intrinsic' value, ${ }^{255}$ which provides a high degree of protection to individual rights holders from interference by society and the state. According to Baker, mere harm is not sufficient grounds to limit the individual right to free speech; something more, such as breach of another individual's rights, is required. ${ }^{256}$ Baker seems to assume that the harms caused by hate speech are merely 'instrumental' 257 - that the only harm it causes is inciting listeners to commit acts of discrimination or violence towards members of the target. Baker seems to ignore that hate speech can cause serious, direct personal harms to members of the target group. ${ }^{258}$

Baker also appears to assume that individual autonomy can be limited or undermined only by state regulation, and not, for example, by the actions of other individuals. This assumption is open to question, particularly given the harms of hate speech outlined above. In addition, Baker seems to prioritise the autonomy of the speaker, rather than that of the target of hate speech. His failure to consider the effect of hate speech on its individual targets, and particularly on their ability to live autonomously, seriously weakens his argument. Given the serious harms caused by hate speech, and the extent to which it undermines the autonomy of its victims, it is arguable that the regulation of such speech is justified.

\section{Serious Offence and the Regulation of Hate Speech}

Although Mill argues that harm justifies limits on speech, and Delgado and Stefancic have argued persuasively that hate speech causes serious harm, there is some doubt as to whether hate speech in fact causes harm to the standard required to justify regulation. ${ }^{259}$ This Part examines whether 'offensiveness' is an alternative basis for regulating hate speech. This issue is particularly important in an Australian context, because 'offence' is one type of vilification prohibited by Part IIA of the $R D A$.

Joel Feinberg has argued that, in certain circumstances, offensiveness (rather than the 'harm' standard required by Mill) is sufficient justification for regulating speech. ${ }^{260}$ Importantly, Feinberg has clarified that 'offensiveness' is not assessed merely by reference to a personal or subjective response to certain words or images; it is determined objectively, based on the standards of a reasonable person. ${ }^{261}$ He has also argued that offensiveness should not be equated with trivial

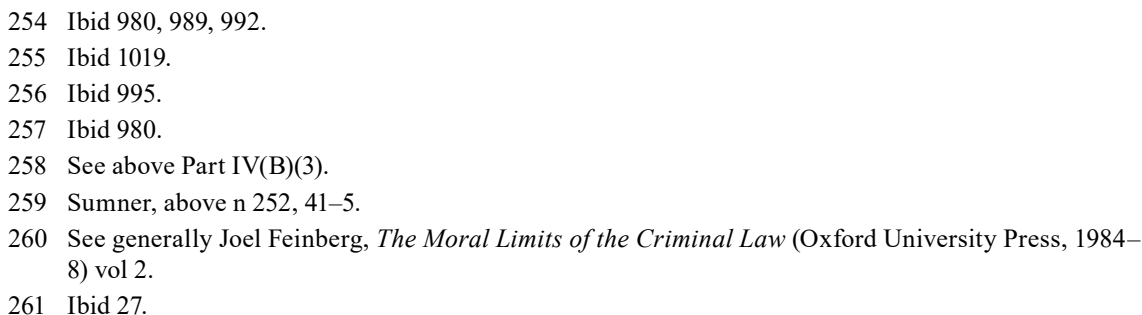


nuisances; his definition of offence is limited to serious or profound offence. ${ }^{262}$ Feinberg has specifically addressed the issue of racial insults and epithets, and he highlights several factors which indicate that they may be considered seriously offensive. Feinberg notes that racial insults, particularly when directed at a particular person or group, undermine the victim's dignity, as they impact on the person's worth and identity. ${ }^{263}$ Like Delgado and Stefancic, Feinberg argues that racial identity is a deeply held personal value. ${ }^{264}$ Racial insults and epithets can cause, and are often intended to cause, anger, fear and humiliation. ${ }^{265}$ The effect of such conduct is particularly significant regarding racial groups which are vulnerable minorities. ${ }^{266}$ This is especially so when the conduct is abusive and mocking towards the disadvantaged group. ${ }^{267}$ Feinberg argues that the history of the treatment of the particular group is relevant in determining the seriousness of particular conduct, particularly when this history involves serious mistreatment such as torture, slavery or genocide. ${ }^{268}$ Similar to Delgado and Stefancic, Feinberg argues that particular incidents must be considered in their relevant social and historical context. This involves consideration, for example, of topics and issues of known sensitivity for a particular individual or group, such as words or images which glorify the Holocaust (in relation to a Jewish audience), or which present slavery, segregation or racial lynching in a positive light (to an African American audience). ${ }^{269}$ Another relevant factor is whether the conduct in question has any social value, such as whether it is part of a legitimate public discussion on a political issue. ${ }^{270}$ Feinberg argues that conduct which conveys no clear message, or which is merely abusive or mocking, may properly be regulated. ${ }^{271}$

It is arguable that the factors listed by Feinberg as characterising certain conduct as seriously offensive are also relevant to the issue of autonomy and human development. That is, conduct which causes serious and profound offence is also likely to undermine the autonomy, and limit the personal development, of individuals who are the targets of such conduct. The promotion of human autonomy therefore provides an additional reason for regulating such conduct. Feinberg's approach also respects the autonomy of the speaker, as it applies only to serious and profound incidents of hate speech.

One factor listed by Feinberg is, however, potentially troubling. This is whether the allegedly offensive conduct is 'reasonably avoidable' by the persons or group

262 Ibid. It is notable that 'profound and serious' is also the standard adopted by Australian judges to attract liability under the provisions of the RDA s 18C: see Eatock $v$ Bolt (2011) 197 FCR 261, 325 [268] (Bromberg J), quoting Creek v Cairns Post Pty Ltd (2001) 112 FCR 352, 356-7 [16] (Kiefel J); Bropho v Human Rights and Equal Opportunity Commission (2004) 135 FCR 105, 124 [70] (French J); Jones $v$ Scully (2002) 120 FCR 243, 269 [102] (Hely J).

263 Feinberg, above n 260, 59-60.

264 Ibid 87.

265 Ibid 21.

266 Ibid 28-9.

267 Ibid.

268 Ibid 93.

269 Ibid 232-5.

270 Ibid 92.

271 Ibid 38, 92. 
who may be affected by it. ${ }^{272}$ Although this factor may be properly regarded as relevant to certain other types of offensive conduct, such as sexually explicit material, its appropriateness in relation to racial abuse is questionable. This is because this factor seems to assume that members of racial minorities are obliged to avoid situations where they are aware that they may be abused or vilified. This is not consistent with the equal worth and standing of all members of society, emphasised particularly by Delgado and Stefancic. Indeed, it seems to encourage members of racial minorities to withdraw from full participation in society, including involvement in educational and employment opportunities. This withdrawal from full participation in society is one of the harms of hate speech particularly emphasised by Delgado and Stefancic, as well as others. ${ }^{273}$ Therefore, this factor should not be considered relevant to the regulation of racial insults and epithets. Apart from this factor, however, Feinberg presents a compelling argument for the regulation of racial hate speech based on serious offensiveness.

\section{Dignity and the Regulation of Hate Speech}

Another alternative ground for the regulation of hate speech is provided by Jeremy Waldron, who has proposed an individual right to freedom from hate speech, based on individual dignity. ${ }^{274}$ Taking issue, in particular, with the arguments presented by Baker, Waldron argues that the harms caused by hate speech are 'constituted by [the] speech, rather than being merely caused by [it]'. ${ }^{275}$ Waldron distinguishes between instrumental and non-instrumental harms caused by hate speech. ${ }^{276}$ His argument for the regulation of hate speech is not based on the assumption (made, for example, by Baker) that the main harm of such speech is that it encourages other people to do something harmful, such as to discriminate against, or to be violent towards members of a particular group. Rather, it is based on the direct, non-instrumental harm to individuals or groups at whom hate speech is directed. ${ }^{277}$ Waldron argues that hate speech attacks a person's 'elementary dignity', ${ }^{278}$ or their status as a full 'member of society in good standing'. ${ }^{279}$ Rather than the term 'hate speech', Waldron prefers the description 'group defamation', as this captures the nature of the harm caused. ${ }^{280}$ Group defamation consists of two elements: first, conduct denigrating a person's 'basic standing'; and second,

273 See above Part IV(B)(3). Vilifying speech also undermines equal democratic participation, as it excludes its victims from full participation in society. This issue is discussed in Part IV(A) of this article. 
the basing of the denigration on a characteristic ascribed to an entire group. ${ }^{281}$ Waldron regards the equal citizenship of all members of society as a fundamental aspect of justice in a democratic society. ${ }^{282}$ However, Waldron bases his argument for hate speech laws explicitly on the value of individual dignity, rather than on broader political principles. ${ }^{283} \mathrm{He}$ argues that such laws are necessary to ensure basic respect for a person as a human being. ${ }^{284}$

The factors listed by Waldron as to why hate speech undermines a person's human dignity are also relevant to the issue of autonomy and human development. That is, hate speech not only undermines human dignity, but it is also likely to undermine the autonomy, and limit the personal development of individuals who are the targets of such conduct. The promotion of human autonomy therefore provides an additional reason for regulating such conduct. ${ }^{285}$

Waldron highlights the seriousness of hate speech, in that it is commonly used to attack members of vulnerable minorities on the basis of imputed group characteristics. ${ }^{286}$ Like Delgado and Stefancic, Waldron notes that the harms of individual incidents of hate speech are cumulative and long-lasting. ${ }^{287} \mathrm{He}$ also argues that the effect of particular words and images must be considered in their historical context, including any history of slavery, racism and violence towards particular racial groups. ${ }^{288} \mathrm{He}$ argues that it is extremely difficult for member of vulnerable minorities to go about their 'ordinary conduct of life' in an environment pervaded by hate speech. ${ }^{289}$ It is arguable, therefore, that hate speech seriously undermines the choices and opportunities available to members of society who already experience severe hardship due to financial and other reasons. Hate speech limits the autonomy of already disadvantaged and marginalised members of society, and therefore should be regulated. ${ }^{290}$ These harms include the denigration and stigmatising of entire groups, which can lead to the isolation and exclusion of these groups and their individual members. ${ }^{291}$

281 Ibid 57. Chesterman also notes the similarity between racial vilification laws and group defamation laws, and the connection between the reputation of a group - particularly based on imputed characteristics of group members - and the reputation of individual group members: see Chesterman, above $n$ 3, 213-24.

282 Waldron, The Harm in Hate Speech, above n 2, 69, 82.

283 Ibid 56, 123. However, Waldron argues that banning extreme hate speech is a 'public good': at 93.

284 Ibid 92.

285 The speaker's autonomy must also be respected. Part $\operatorname{IV}(B)(7)$ of this article outlines reasons why regulation of hate speech does not unduly restrict the autonomy of speakers.

286 Waldron, The Harm in Hate Speech, above n 2, 123.

287 Ibid 97.

288 Ibid 102-3.

289 Ibid 83.

290 Racial vilification laws generally apply to members of all racial groups — whether they are a majority or minority, and whether or not they have been historically disadvantaged or oppressed: ibid 9 . Although this equal coverage is consistent with basic liberal values and particularly principles of non-discrimination, it does however weaken Waldron's argument regarding the seriousness of all incidents of hate speech.

291 Ibid 58-9. 


\section{Arguments Based on Autonomy and Dignity Are Consistent with Racial Vilification Laws}

This section has argued that racial vilification laws are consistent with arguments for free speech based on autonomy and dignity. Mill and others have provided convincing arguments that access to ideas and opinions can facilitate individual development and, in rare cases, even profound advancement. However, Mill's argument sought to facilitate discussion of the 'highest subjects', ${ }^{292}$ and was never an argument for unrestricted speech. Mill clearly recognised the possible harms of certain speech, and the need for regulation in certain circumstances.

Baker and others have argued that communication is necessary to form strong interpersonal bonds and relationships. However, Delgado and Stefancic have documented the serious and long-lasting harms caused by hate speech, both at a personal and a societal level. It has been argued here that there are several grounds for regulating racial vilification, such as the harms caused, on the basis of serious offence, and also on the grounds of human dignity.

In terms of balancing the autonomy of the speaker and that of the targets of hate speech, two points should be noted. First, hate speech laws apply only to 'public' conduct, and do not apply to private conversations. ${ }^{293}$ The autonomy of the speaker therefore is limited by such laws only in relation to 'public' speech. Arguably, public speech is more harmful in its effects, and more likely to harm a larger group of people than a private communication. Also, a speaker's autonomy to speak hatefully in private conversations is not limited. Second, hate speech laws apply only a narrow band of speech, and therefore they do not impinge unduly on a speaker's autonomy. Such laws generally apply only to the most extreme forms of hate speech. ${ }^{294}$ This restriction enables a speaker to exercise and develop their autonomy in any way that falls short of this narrow band of speech regulated by racial vilification laws. This restriction also protects and promotes the autonomy of targets of hate speech, by protecting them from the most harmful types of hate speech.

\section{The Value of Inquiry}

This Part examines a third group of arguments for free speech. These arguments emphasise the importance of open discussion, on certain topics, which is free of government regulation. The arguments claim that the search for truth, through

292 Mill, above n 171, 66.

293 Waldron, The Harm in Hate Speech, above n 2, 38-9. See, eg, RDA s 18C.

294 Waldron, The Harm in Hate Speech, above n 2, 45. As detailed in Part IV(B)(5) of this article, there are strong arguments for regulating seriously offensive racist speech. Waldron argues that hate speech laws should apply only to 'visible' and 'enduring' forms of communication (such as broadcasted or published messages), and not merely to verbal abuse, which he regards as 'ephemeral': at 72. However, this seems to contradict his argument that the effects of individual incidents of hate speech need to be seen cumulatively, and not in isolation. Also, in terms of harm, it is arguable that the nature of the message conveyed is more significant than the form of the communication, including whether it is 'enduring' or 'visible'. 
open and public competition between ideas, is essential for social progress and for achieving consensus on social issues. This Part will first examine the arguments of John Stuart Mill, an early and powerful proponent of these ideas. Next, it will examine the adoption of Mill's arguments into American free speech doctrine. Finally, this Part will examine the extent to which these arguments for free speech are consistent with, or even support, the regulation of hate speech. Ultimately, this Part concludes that the value of inquiry does not preclude regulation of racial vilification, but in fact supports regulation.

\section{John Stuart Mill and the Importance of Open Discussion}

As described earlier in this article, ${ }^{295}$ John Stuart Mill argued that open discussion of ideas would lead to the best ideas and opinions being heard, considered and accepted. ${ }^{296}$ Mill particularly emphasised the negative impact of persecution, or suppression of ideas (whether true or untrue), on the search for truth. ${ }^{297}$ It is notable that Mill was concerned not so much with the state or with legal regulation of speech $^{298}$ in particular, but, rather, with the ability of powerful social institutions (and in particular, the established church) to persecute individuals who expressed ideas and opinions which challenged their power. ${ }^{299}$ To a lesser extent, Mill was also concerned with the ability of public majorities to silence 'immoral' opinions, through forms of social stigma. ${ }^{300}$

Mill did not directly address how the 'best' ideas in fact originated, but he assumed that, in every society, there were a small number of geniuses ('the best men [sic], [with] the noblest doctrines'). ${ }^{301}$ Mill contrasted the unconventional ideas $^{302}$ of these people with the received opinion believed by most other members of society. He argued that, through the process of open and public discussion, individuals discovered 'true' or better ideas and opinions, and that falsehoods were exposed and rejected. ${ }^{303} \mathrm{He}$ argued that this was beneficial not only for individual development, but also for the progress of society. ${ }^{304}$ Mill argued that his principle of free speech should apply to all topics of discussion, including morality, politics and religion. ${ }^{305}$

Mill advanced three main arguments in support of his account of free speech. First, he argued that 'popular opinion', ${ }^{306}$ or what the majority of people believed in relation to a particular topic, was often found, subsequently, to be either

295 See above Part IV(B)(1).

296 Mill, above n 171, 68-70.

297 Ibid 55.

298 Here, 'speech' includes restrictions on the publication of books and newspapers.

299 Mill, above n 171, 62-3.

300 Ibid 65-6.

301 Ibid 59.

302 See ibid 63-4. Mill provided the historical examples of Socrates and Christ: at 59-60.

303 Ibid $68-70$.

304 Ibid 68. Mill assumed that the development of society happens through the development of ideas.

305 Ibid 66-7. Mill argued for the discussion of 'the highest subjects' and 'the greatest questions'.

306 Ibid 77. 
completely false, or not the complete truth. ${ }^{307}$ Further, Mill argued that the most unconventional ideas and opinions could, in fact, turn out to be true. ${ }^{308} \mathrm{He}$ argued that individuals who expressed unpopular or dissenting views needed to be protected from the ignorant majority, who tended to persecute dissidents, rather than face the difficult task of questioning their own beliefs. ${ }^{309}$

Second, Mill argued that any suppression of speech was always motivated, in the final analysis, by self-interest. ${ }^{310}$ In other words, powerful institutions such as the established church used censorship and persecution of heretics to maintain their power, by controlling the types of information and ideas people are able to hear and consider. ${ }^{311}$ By preventing access to certain views and opinions that challenge their own views and opinions, powerful institutions are able to maintain, and expand, their hegemonic power. ${ }^{312}$ This argument links in with the previous argument, as unconventional ideas and opinions are often those that challenge the views preferred by powerful individuals and institutions in any given society.

Third, Mill's theory combined great faith in individual human reasoning with extreme scepticism regarding the judgment of majorities and institutions. On the one hand, Mill assumed that people would recognise and accept 'true' ideas when those ideas were presented to them, and when logical arguments were provided. ${ }^{313}$ On the other hand, Mill assumed that institutions, such as the established church, were always influenced by bias and self-interest, and therefore could not be trusted with any regulatory power over the communication of ideas. ${ }^{314}$ Even if such institutions were not consciously biased, Mill argued that any attempt by them to regulate speech or communication was based on an unjustified assumption that final and complete truth had already been attained. Mill argued that humans are inherently fallible in terms of knowledge, and that powerful institutions should not be able to restrict access to information or ideas by any other person or group. ${ }^{315}$

To appreciate the breadth of Mill's argument against regulation, it should be noted that he argued that dissemination and discussion of even false ideas should not restricted. ${ }^{316}$ Mill argued that exposure to false ideas enables true ideas to be tested and better understood. ${ }^{317}$ Exposure to false ideas, he argued, would assist people to understand common arguments against true ideas, and to understand the underlying 'grounds' or reasons for true opinions. ${ }^{318}$ Further, Mill argued that 
people needed to know true ideas as 'living belief', ${ }^{119}$ and not merely as 'dead dogma' or 'prejudice'. ${ }^{320}$ This has been described as an 'intellectual gym' argument for free speech, and is based on the belief that 'minds can be strengthened' by exposure to false ideas. ${ }^{321}$ This argument highlights Mill's extreme confidence in people's ability to distinguish true or valuable ideas from false ones. ${ }^{322}$

\section{Adoption of Mill's Ideas into American Free Speech Doctrine}

Although Mill popularised the notion of free speech as facilitating competition between ideas, the term 'marketplace of ideas' originated in American free speech doctrine. ${ }^{323}$ Specifically, the term has been traced to Holmes J (Brandeis J concurring), who referred to the 'free trade in ideas' as the fundamental principle underpinning freedom of speech. ${ }^{324}$ In his famous Abrams $v$ United States judgment, Holmes J asserted two key principles: first, 'that the best test of truth is the power of the thought to get itself accepted in the competition of the market', and second, 'that truth is the only ground upon which [social policy] safely can be carried out'. ${ }^{325}$ These statements, and the principles that underpin them, have been adopted in numerous subsequent First Amendment decisions, and have powerfully shaped popular conceptions of free speech. ${ }^{326}$

There are important differences, however, between Mill's original conception of free speech and the current popular understanding of free speech. Significantly, as noted above, Mill's conception of free speech was not concerned primarily with the state or with legal regulation of speech. ${ }^{327}$ American free speech doctrine, however, is based on a particular constitutional provision, and it inevitably focuses on the state. Specifically, it is premised on promoting free speech by placing constraints on state actions and regulations. Thus, American free speech doctrine has two key features: first, it focuses exclusively on state regulation of speech, rather than any other factors affecting an individual's ability to speak and be heard ${ }^{328}$ second, it operates specifically as a limit on state power to regulate speech, rather than as a source of power to regulate speech. ${ }^{329}$ As mentioned

319 Ibid 71.

320 Ibid 68.

321 Paul H Brietzke, 'How and Why the Marketplace of Ideas Fails' (1997) 31 Valparaiso University Law Review 951, 957.

322 Ibid 956-7. This assumption can be traced back to John Milton, Areopagitica: A Speech for the Liberty of Unlicensed Printing to the Parliament of England (Floating Press, first published 1644, 2009). See ibid 951, which notes similarities between the arguments of Mill and Milton.

323 See generally Brietzke, above n 321; Stanley Ingber, 'The Marketplace of Ideas: A Legitimizing Myth' [1984] Duke Law Journal 1.

324 Abrams $v$ United States, 250 US 616, 630 (Holmes J) (1919).

325 Ibid.

326 See generally Ingber, above n 323.

327 Kent Greenawalt seems to regard Mill's conception of free speech as a theory regarding suppression of speech by the government: Kent Greenawalt, 'Free Speech Justifications' (1989) 89 Columbia Law Review 119, 130. With respect, Mill's conception of free speech is not a theory of the state.

328 Fiss, above n 26, 61-2.

329 Ibid. 
earlier in this article, ${ }^{330}$ Mill's account of free speech was not specifically focused on suppression of ideas and opinions by the state. Rather, his account focused on the power of particular institutions, and of individuals acting collectively, to effectively suppress certain ideas and opinions.

A particular feature of American free speech doctrine is the emphasis placed on state 'neutrality' in relation to speech regulation. ${ }^{331}$ That is, free speech is understood as specifically prohibiting the state from regulating speech in a way that favours, or that disfavours, certain ideas or opinions. ${ }^{332}$ In American free speech language, this type of regulation is known as 'viewpoint' regulation. ${ }^{333}$ The importance of the state remaining neutral in relation to speech regulation is said to be based on two main reasons. First, it is argued that state neutrality is necessary in order for citizens to be able to decide issues for themselves. ${ }^{334}$ Second, there is concern that advocating for or against a particular point of view would involve the state in favouring one group of people over another. ${ }^{335}$

As mentioned above, a main feature of American free speech doctrine is that it is purely 'negative'. That is, it operates to limit state power, rather than to confer power on the state regarding the regulation of speech. According to this view, the state has no positive role in promoting truth. ${ }^{336}$ This is based on the Millian assumption that the state regulates speech only in order to protect and promote its own interests. According to this view, the state cannot be trusted to promote the truth, but only to promote its own (self-interested) version of the truth. ${ }^{337}$

A final notable feature of American free speech doctrine is the notion that free speech 'trumps' any other policy goal of government. The most notable proponent of this view is Ronald Dworkin, who argued that free speech in fact incorporates and respects principles of equality, as it ensures that everyone is treated with 'equal concern and respect'. ${ }^{338}$ This is because free speech (in the purely negative sense in which he conceived it) prevents the government from supressing the speech of any particular person. ${ }^{339}$

335 Ibid 17. A related concern, which is a strong theme in American constitutional law, relates to the regulatory power of the state being captured or controlled by 'factions' (or powerful interest groups), thus enabling that group to impose its norms on the rest of society: at 21. See also Molnar, above n 47, 17-8; Garton Ash, above n 30, 224-5.

336 Fiss, above $\mathrm{n} 26,17$.

337 Ibid. See also Chesterman, above n 3, 231.

338 Ronald Dworkin, Taking Rights Seriously (Harvard University Press, 1977) 273.

339 Ibid 263-76. Dworkin's views on free speech are examined in Part IV(A)(3) of this article. 


\section{The Value of Inquiry Supports Regulation of Racial Vilification}

This Part considers whether the value of inquiry supports, or at least is not inconsistent with regulation of racist hate speech. First, it considers the argument that regulation of racist speech is justified, because the 'race debate' is 'over'. Second, it considers the argument that racist speech is merely abuse and invective, rather than a contribution to knowledge or debate. Third, it considers the argument that racist speech actually undermines rational debate, which is directly contrary to the value of inquiry. Fourth, it examines arguments that racist speech is a form of 'unfair competition', because, by denigrating members of particular groups, it illegitimately excludes certain points of view from the marketplace. Ultimately, this Part concludes that regulating racist hate speech is consistent with the value of inquiry.

Jeremy Waldron argues that racist hate speech may permissibly be regulated because the 'debate about race is over' ${ }^{340} \mathrm{He}$ emphasises that there is no biological or genetic basis for ideas of racial superiority or inferiority. ${ }^{341}$ Clearly, Waldron is correct in stating that there is no scientific basis for many of the ideas expressed in racist hate speech. However, Waldron seems to ignore that freedom of speech, and the value of inquiry, applies not only to statements of fact, but also to statements of opinion. This is clear, for example, from Mill's exposition of free speech, and his emphasis on 'received opinions' and unconventional ideas. ${ }^{342}$ Therefore, Waldron's argument that racist ideas are factually inaccurate is not a complete argument for the permissibility of regulation. However, his argument clarifies the real issue in this debate: whether the dissemination of certain opinions should be regulated, even if they have no factual basis. A second (and related) point apparently overlooked by Waldron is that racial vilification laws regulate debate between members of the public. They are not exclusively (or even primarily) focused on scientific debate, or debate between scientists. ${ }^{343}$ This point highlights the close connection between political arguments for free speech, ${ }^{344}$ and the arguments examined in this Part. Public debate regarding race issues, insofar as it is regulated by racial vilification laws, is primarily a political and social debate. In this light, the strongest argument for not regulating speech relating to race issues is that allowing debate may lead to the adoption of the best policies in this area.

As explained above, factual inaccuracy per se is not a complete argument for the permissibility of regulating racist hate speech. However, other arguments for the permissibility of regulating such speech have been made. Delgado and

340 Waldron, The Harm in Hate Speech, above n 2, 195.

341 Ibid.

342 Mill, above n 171, 58. See the discussion of Mill's arguments in Parts IV(B)(1) and IV(C)(1) of this article.

343 Greenawalt argues that debate between scientists, or experts in a particular field, should be less regulated than debate between members of the public: see Greenawalt, above n 327, 136-7. This argument is supported by the existence of 'defences' to racial vilification, such as those contained in the $R D A \mathrm{~s} 18 \mathrm{D}$.

344 See above Part IV(A). 
Stefancic argue that many vilifying remarks are essentially insults or invective, rather than contributions to a debate. ${ }^{345}$ They emphasise that these types of speech do not put forward any clear proposition or argument capable of being agreed with or disputed. ${ }^{346}$ For these authors, the value of inquiry necessarily involves an exchange of ideas or opinions, or a reciprocal dialogue between two or more people. $^{347}$ They argue that racial insults do not have this quality, as they are essentially a form of intimidation or harassment. ${ }^{348}$ However, although many types of conduct caught by racial vilification laws constitute intimidation or harassment, not all such conduct falls into this category. ${ }^{349}$ Therefore, this argument does not provide a complete justification for the permissibility of regulation. Further, it is arguably appropriate to give a generous interpretation to the concept of 'inquiry' and the types of discussion that should not be legally regulated. ${ }^{350}$ This is similar to the broad scope of permitted 'political contributions' in relation to democratic arguments for free speech. ${ }^{351}$

A third argument for the permissibility and indeed importance of regulating racist hate speech is that such speech promotes views that are not only false and harmful, but also irrational. Scholars such as Allport and Matsuda emphasise that the value of inquiry is underpinned by assumptions of human rationality and independent, critical thinking. ${ }^{352}$ It is questionable whether, generally, people do think critically about what they hear, and that they decide issues based on logic and evidence. ${ }^{353}$ Allport argues that racist speech promotes racial stereotypes and prejudice, and particularly notions of racial inferiority, amongst those who are exposed to it. ${ }^{354}$ He argues that promoting racial prejudice encourages irrationality in two ways. First, racial prejudice is based on a negative attitude or feeling, rather than on logic and evidence. ${ }^{355}$ Second, racial prejudice assumes that all members of a particular group have certain characteristics. ${ }^{356}$ Allport argues that the promotion of prejudiced attitudes is antithetical to the value of inquiry, as such attitudes are based on irrational impulses, and tend to be resistant to evidence. ${ }^{357}$ Allport and Matsuda present a powerful argument for the permissibility of regulating racist hate speech, which is supported by arguments based on the importance of human

Delgado and Stefancic, 'Four Observations about Hate Speech', above n 20, 369. The authors cite, as an example, the remark 'You dirty $\mathrm{N}_{-}$[sic], ... go back to Africa'.

346 Ibid. See also Chesterman, above n 3, 223-4; Barendt, above n 29, 10-11.

347 Delgado and Stefancic, 'Four Observations about Hate Speech', above n 20, 369.

348 Ibid.

349 For example, the $R D A \mathrm{~s} 18 \mathrm{C}$ applies to conduct which is merely 'offensive'.

350 See generally Schauer, above $\mathrm{n} 2$.

351 Dworkin, 'Foreword', above n 132, vii-viii.

352 Gordon W Allport, The Nature of Prejudice (Addison-Wesley Publishing, 1954) 189-92; Matsuda, above $\mathrm{n} 250,2339$. See also Barendt, above n 29, 33; Schauer, above n 2, 17-19. See also the discussion of Mill in Part IV(B) of this article.

353 Matsuda, above n 250, 2339.

354 Allport, above n 352, 9-12, 14-15.

355 Ibid 22.

356 Ibid 5-11. This is consistent with the concept of group defamation, examined in Part IV(B)(6) of this article.

357 Allport, above n 352, 9. 
autonomy (and, in particular, respecting the autonomy of those exposed to such speech). ${ }^{358}$

As we have seen, in Mill's exposition of the value of inquiry, he particularly valorised dissenting voices and the unconventional ideas of minorities. ${ }^{359}$ Mill argued that these voices challenged orthodox views or 'dogma' on particular topics. ${ }^{360}$ By exposing falsehoods, these speakers enable true ideas to be discovered. In this light, it is often asserted that people engaging in racist hate speech are presenting dissenting views and are challenging orthodoxy. ${ }^{361}$ However, Delgado and Stefancic emphasise that racial vilification is commonly used by dominant social groups against members of less powerful minority groups. ${ }^{362}$ They argue that racial vilification is used by speakers with power to silence members of minority groups. ${ }^{363}$ Fiss argues that laws regulating racial vilification are justified because they ensure fair competition in the marketplace of ideas. ${ }^{364} \mathrm{He}$ argues that members of racial minorities are already disadvantaged in seeking to have their views heard, as they are less able to access mainstream media outlets. ${ }^{365} \mathrm{He}$ argues that racist speech is part of 'dominant narratives' that reinforce the values and interests of the dominant class in society. ${ }^{366}$

Building on similar ideas, Lawrence argues that regulating racist hate speech is justified, as the prejudice it promotes 'causes all of us to misapprehend the value of ideas in the market' ${ }^{\prime}{ }^{367} \mathrm{He}$ argues that ' $[\mathrm{r}]$ acist speech ... distorts the marketplace of ideas by muting or devaluing the speech of blacks and other non-whites' ${ }^{368}$ In this light, racial vilification can be regarded as a type of anti-competitive conduct, as it excludes certain ideas from the market, for reasons other than the merits of the particular idea. ${ }^{369}$ Fiss argues that it is legitimate to regulate anticompetitive conduct in the economic market, and arguably even more important to do so in relation to political debate. ${ }^{370}$ As mentioned above, the intended beneficiaries of the marketplace of ideas are members of the public generally. ${ }^{371}$

358 See above Part IV(B)(2)

359 See above Part IV(B)(1)

360 Mill, above n 171, 68.

361 See, eg, the discussion of Ronald Dworkin's views in Part IV(A)(3) of this article.

362 Delgado and Stefancic, 'Four Observations about Hate Speech', above n 20, 355, 368.

363 Ibid.

364 Fiss, above $\mathrm{n} 26,21$.

365 See ibid 16. Fiss argues that access to the media and other sources of information is very restricted in modern societies: see generally ibid. Further, Garton Ash argues that the popular news media often presents negative stereotypes regarding certain racial minorities, such as repeated stories about 'Muslim terrorists' and 'criminals'. This is because promoting prejudiced views is known to improve the popularity, and thus the profitability, of such media outlets: see Garton Ash, above n 30, 235-6.

366 Delgado and Stefancic, Must We Defend Nazis?, above n 222, 71-2, 88-90. Ingber goes further, arguing that the 'marketplace of ideas' is simply a 'legitimizing myth', insofar as it suggests that the dominant ideas in a given society achieved dominance by their inherent merits alone: Ingber, above n 323,31 .

367 Lawrence, above n 249, 470.

368 Ibid.

369 Ibid.

370 Fiss, above n 26, 16.

371 See especially the examination of Mill's account of free speech in Part IV(B)(1) of this article. 
Thus, it is permissible to regulate the conduct of particular individuals, in order to ensure that the marketplace operates effectively. ${ }^{372}$ As Mill argued, the public is harmed when potentially valuable ideas are illegitimately excluded from the marketplace. ${ }^{373}$ Therefore, regulation of racial vilification ensures that all members of the public have access to the widest range of ideas, and particularly the 'eminent thinkers' valorised by Mill. ${ }^{374}$ This type of regulation is also entirely consistent with modern principles of economic regulation. ${ }^{375}$

In relation to the issue of state neutrality, it is arguable that the state is not neutral in relation to racist speech. It is common for governments to invoke subtle forms of racist speech, in order to bolster their popularity. ${ }^{376}$ In a democracy, governments rely on popular support to be elected into office, and this is often gained by vilifying particular minorities. ${ }^{377}$ Racial vilification laws apply to politicians and to members of government, and it is notable that politicians have been the subject of several high profile racial vilification cases in Australia. ${ }^{378}$ Given the ability of prominent individuals to influence public attitudes, ${ }^{379}$ it is particularly important that racial vilification laws apply to such individuals.

As noted above, it is often asserted that the search for truth is an overriding policy goal. However, contrary to this assertion, other goals are also important. Particularly important, in relation to racist hate speech, is the prevention of harm to individuals and groups. As described above, ${ }^{380}$ racial vilification causes significant harm to members of racial minorities. Members of these groups are particularly vulnerable to harm, due to their marginalised social, political and economic status. ${ }^{381}$ It is arguable that any benefits of allowing racist speech must be weighed against the harms to individuals and groups. ${ }^{382}$ In relation to the types of racist speech regulated by racial vilification laws, the benefits of allowing such speech seem minimal, and the harms are widespread and significant. Therefore, regulation of such speech is justified.

373 Mill, above n 171, 68.

374 Ibid 59.

375 It should be noted that the laissez faire or 'free market' economic principles on which the 'marketplace of ideas' is based have been long rejected in modern democratic political systems: see Jones, above n 224, 321-2.

376 McNamara, above n 10, 14-15.

377 See, eg, Megan Davis, 'A Culture of Disrespect: Indigenous Peoples and Australian Public Institutions' (2006) 8 UTS Law Review 135 for several examples of denigrating remarks made by Australian Members of Parliament regarding Australian Indigenous peoples.

378 Ibid.

379 Allport emphasises the powerful role of prominent individuals in the spread of racist attitudes: see Allport, above n 352, 57-8.

380 See above Part IV(B)(3).

381 Ibid.

382 See generally Waldron, The Harm in Hate Speech, above $\mathrm{n} 2$. 


\section{v CONCLUSION}

This article has outlined three types of arguments commonly made in support of free speech. First, it examined arguments that free speech facilitates the formation of informed opinion, which is necessary for democracy or self-government. Second, it examined the connection between free speech and personal autonomy and dignity. Finally, it examined the connection between free speech and forms of inquiry that support social progress and the discovery of the best policy options. Each of these types of arguments justifies certain restrictions on government regulation of speech. However, on closer inspection, these arguments also justify restricting certain speech acts, including racial vilification, in certain circumstances.

In relation to arguments based on democracy and self-government, racial vilification can effectively 'silence' certain people and groups, which excludes them from participating in democratic debate and decision-making. Therefore, regulating racial vilification is necessary and justified, in order to ensure equal political rights - and an equal ability to participate in and contribute to political debate - for all members of society. In relation to personal autonomy and dignity, free speech can facilitate personal 'flourishing'; however, racial vilification can cause severe and long-term personal harms. Regulation of racial vilification is therefore justified, to protect vulnerable members of social minorities from serious harms. In relation to the value of inquiry and public debate on social issues, racial vilification can distort such debates by denigrating certain individuals and by promoting prejudice rather than rational decision-making. Regulation of racial vilification is therefore justified, in order to ensure that potentially valuable ideas are judged on their merits, rather than being excluded on the basis of racial prejudice and stereotypes.

More broadly, this article has challenged the notion that unrestricted speech is a self-evident and unqualified good. Rather, it has argued that free speech arguments themselves provide justification for regulation of certain types of speech. By clearly identifying the values and assumptions underlying arguments commonly made in support of free speech, this article seeks to improve the quality of debate surrounding the regulation of racial vilification. This type of informed discussion has the potential to influence the development of legal policy and legal doctrine surrounding legal regulation of this and other forms of speech. 